Article

\title{
Soil and Water as Resources: How Landscape Architecture Reclaims Hydric Contaminated Soil for Public Uses in Urban Settlements
}

\author{
Isotta Cortesi ${ }^{1}$, Laura Valeria Ferretti ${ }^{2, *}$ and Federica Morgia ${ }^{2}$ \\ 1 DiARC, Università degli Studi di Napoli Federico II, 80130 Napoli, Italy; isotta.cortesi@unina.it \\ 2 DiAP, Sapienza Università di Roma, 00185 Roma, Italy; federica.morgia@uniroma1.it \\ * Correspondence: lauravaleria.ferretti@uniroma1.it
}

Received: 3 September 2020; Accepted: 5 October 2020; Published: 24 October 2020

check for updates

\begin{abstract}
Soil is one of the fundamental components for life on Earth, but today, as a consequence of humans' unsustainable actions, soil is polluted, distressed and spoiled. In contemporary practice design, we recognize the importance of the soil quality to structure new discourses in landscape practice. The central role in this process is undoubtedly played by the value a healthy soil has for the community and for the environment. The strategic design of wet and hydric landscapes is certainly an essential aspect for the regular and exceptional management of the effects produced by pollution and climate change. The research develops the soil as a key subject in the landscape design, specifically in hydric environments where water represents an important factor. The essay is divided into three parts: resources and opportunities of disturbed wet soil, successfully built public space where soil remediation transformed heavy polluted industrial urban sites in fertile public ecosystems within the dense urban structures, and soil design as a domain of urban resilience. The landscape project as an integrated project has spread the seeds of a new approach to the consideration of the contemporary city in an ecological manner.
\end{abstract}

Keywords: soil; water; contamination; public places; waste; landscape architecture; water sensitive cities; overflow and flood; remediation; unstable urban landscapes

\section{Introduction}

In contemporary practice, we recognize the importance of the soil quality to structure new discourses on the city. In fact, after several decades where soil has been systematically exploited and polluted as if it were an interminable resource, now we face an important change in paradigm on which we build our discussion [1]. Particularly, in this essay, we focus on how landscape architecture responds in relation to the soil quality to design open spaces.

Soil is one of the fundamental components for life on Earth, but today, as a consequence of humans' unsustainable actions, soil is polluted, distressed and spoiled. Moreover, soil has the capacity to improve the climate or poison the atmosphere. For this reason, it should be at the center of future environmental and urban policies. The central role in this process is undoubtedly played by the value a healthy soil has for the community and for the environment.

Climate change, exceptional floods, atmospheric precipitation and sea level rise have profound effects on soil quality: erosion, pollution-due to the impact of overflow water management systems—-soil contamination—due to flooding —and soil damage—due to soil sealing [2].

An important FAO research [3] affirms that soil plays a key role in water supply and is resilient in floods and in droughts. It captures and stores water, making it available for crops, minimizes surface evaporation while maximizing water use efficiency in agriculture [4], and it interacts with the climate, 
mitigating the effects of heating in cities. Its ability to retain water is important both in periods of drought and in the increasingly frequent periods of heavy rains [5], because it slows down the outflow.

The strategic design of wet and hydric landscapes is certainly an essential aspect for the regular and exceptional management of the effects produced by climate change.

Since the late 1960s, there has been a growing interest in environmental issues: the habitability of the planet and the sustainability of resources in relation to the population. Every year, since 22 April 1970, we celebrate Earth Day, renewing the principles expressed by Barry Commoner [6], who was the main proponent of the four laws of Ecology:

1. Everything is connected to everything else. There is a single ecosphere in which all living organisms survive and the effects on one of them have consequences for all the others;

2. Everything must go somewhere. There is no waste in nature because everything is part of a chain that connects matter and energy;

3. Nature knows best. Every change caused by man can produce damage to the natural system;

4. There is no such thing as a free lunch. In ecology, there is no profit that can be achieved without a corresponding cost.

In this global scenario, architecture and landscape projects are necessary means for the Care of the physical world; while defending it, they understand and revise the causes of the transformation's phenomena. Architecture re-affirms a new ethical value and becomes responsible for a new relationship of stewardship between humans' actions and nature [7].

The architect is, according to Ian McHarg, an ecological planner since he leads the discipline "into a board multidisciplinary tool of resource management and land use planning" [8].

\section{Materials and Methods}

The research develops the soil as a key subject in landscape design, specifically in hydric environments where water represents an important factor. The essay is divided into three parts:

1. First part: The Beauty and the Beast. Resources and opportunities of disturbed wet soil. This part Identifies interventions in which, starting from former landfills, in environments characterized by the presence of water, design intervention has managed to overturn the landfills' conversion into a new hydric ecosystem. The essay proposes a reclamation of disturbed lands and a landfill remediation taxonomy, which implements design strategies focusing on two main topics: the Performance of Nature and the Recovering Landscape, both improving a new Aesthetic of Ecology [9]. Through design and the ecological landscape's restoration, contaminated soils assume new forms and values becoming new landmarks and new contemporary parks, recovering lost cultural and natural values.

2. In the second part we observe, in the built environment, paradigms where the Aesthetic Experience in relation to the Environmental Ethics transforms polluted industrial urban sites into fertile public ecosystems. We discuss European models: successfully built public space where soil remediation has transformed heavily polluted industrial urban sites into fertile public ecosystems within the dense urban built environment. These places are now accessible to people, becoming an active part in the cultural life of cities. This part of the essay develops a possible framework for the conversion of brownfields into new ecosystems where water plays a fundamental role in the remediation processes, structuring different design categories for contemporary public spaces in densely populated cities: Hypernature as Esthetic Experience, Public Nature as City Culture, Operative Nature as Environmental Ethics.

3. The third part explores soil design as a domain of urban resilience. The landscape project as an integrated project has spread the seeds of a new approach to the vision of the contemporary city in an ecological manner. It is a change of direction for which it is not just a matter of greening the cities, strengthening ecological networks or designing gardens, but it is also a matter of more and 
more being done to insert real fragments of nature-efficient ecosystems-into the urban fabric by reconnecting the city with the its original natural context. Water and the related soil project are an essential component of context-based projects because they use existing resources that would otherwise be dispersed and, by introducing a time variable, allow the planning of an incremental evolution of places, this being the concept behind a new generation of landscape urbanism.

In this part we will therefore see how some interventions, namely the soil projects, manage to transform floods or overflow phenomena from risk factors to resources by creating new unstable urban landscapes.

\section{First Part: The Beauty and the Beast. Resources and Opportunities of Disturbed Wet Soil}

In the culture of contemporary design, open spaces for public use acquire the same importance as built space. In the 19th century, Frederick Law Olmsted realized new urban public parks as spaces of urban social, cultural and environmental reform. For a founding father of American landscape architecture, these kinds of new public spaces "performed in two ways: first, they were environmental cleaning machines, open spaces of healthy sun light, well-drained soils, and shady groves of trees reducing temperatures, absorbing carbon dioxide, and releasing oxygen. Landscape architectural works such as urban parks, promenades and boulevards, public gardens, parkways, and suburban residential enclaves were cultural products that responded to, and then altered, the processes of modernization and urbanization" [10] (p. 92).

Due to environmental disasters and a climate change largely caused by human action, the importance of green spaces has increased further. Paradoxically, waste and pollution, especially in the case of wet soil, can be a potential resource for the well-being of the environment in which we live. Nowadays in the context of a "permanent emergency" strategy, to cite Rem Koolhaas, the issue is not the creation of an ideal environment but the opportunistic exploitation of the unexpected, the accidental and the imperfect [11]. Gradually and inevitably, we are learning from our mistakes and attempting to improve upon them with better choices for a more sustainable and resilient design. Nature itself is teaching us how. We must learn from how natural processes self-regulate and apply these conditions to the way in which we design and transform our spaces.

Accumulation of waste is a progressive process which involves a level of soil saturation which the end of the process extends beyond. Soils contaminated by the accumulation of debris from anthropogenic actions, where the waste has stratified, can be transformed into new landscapes. Waste disposal sites have been converted into renovated natural areas with new purposes since the second half of the 20th century [12] (pp. 96-98). It has since then become more popular to work with so-called waste parks or disturbed sites. For these sites to be considered safe, processes of remediation are necessary before the grounds can be used. Frequently, these sites are turned into parks by using water as a fundamental element to trigger this transformation. The remediation project is entrusted to the ecological and sustainable component able to trigger a virtuous mechanism that allows the environment to find a new ecological balance over time.

This essay identifies some illustrative examples of new landscapes created from the transformation of contaminated places strongly characterized by the presence of water. It proposes a taxonomy of landfills and wastewater remediation, through the conversion of disturbed sites into a new wet habitat, which implement different design strategies on two main topics: Performance of nature and Recovering Landscape.

\subsection{Performance of Nature. Design Engages Nature's Intelligence to Reduce Harmful Human Impact}

Landscape ecology studies and aims to understand and improve relationships, such as composition, structure and function, in the ecological process and the landscape system. Ecological restoration is the process of assisting the recovery of damaged, degraded or destroyed ecosystems. Both are focused on reversing the biodiversity extinction crisis. They are expansive breadth of ecological theory, in which 
nature's in-built performance solves the problem of environmental pollution, influencing landscape architecture [13].

Over $80 \%$ of wastewater is discharged into the environment without adequate treatment around the world. The paradigm of wastewater management has to shift from treatment disposal to reuse, recycling, and resource recovery. Meanwhile, an ecologically friendly and cost-effective solution is needed. Many wastewater treatment processes have been designed to improve water quality. From the biological characteristics of the aquatic environment, endemic vegetation, such as water hyacinth, giant reed, microalgae and duckweed, have shown capability in pollutant removal. Duckweed, a kind of floating aquatic plant, is widely distributed around the world and comprised of many species and different genera (Figure 1).

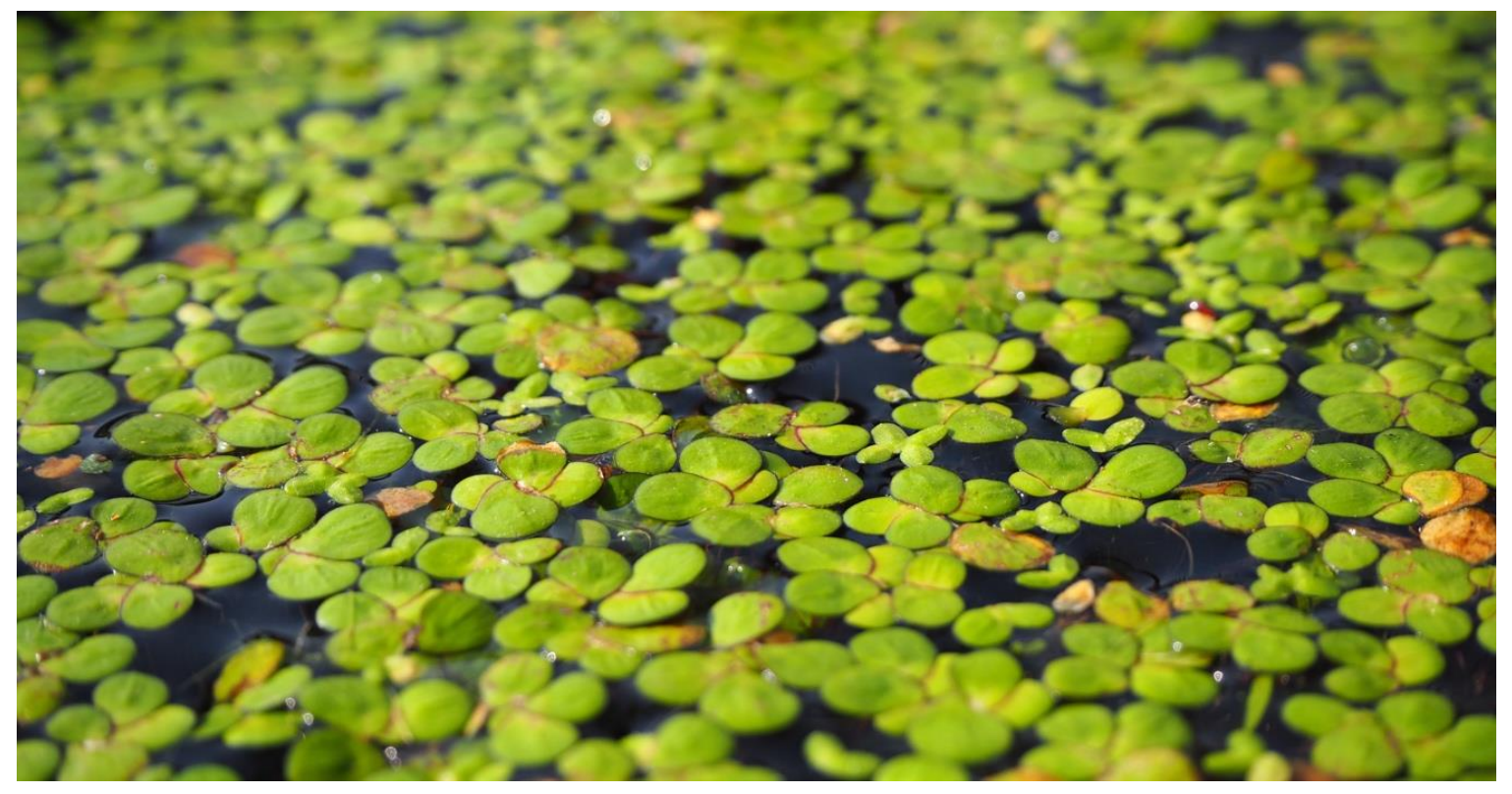

Figure 1. Floating duckweed. Duckweed belongs to the botanical family of Lemnaceae, they are divided into four genera Lemna, Spirodela, Wolffia, and Wolffiella of which, to date, more than 40 species have been identified.

Due to this ability, this plant has already been used for the treatment of domestic, industrial and swine wastewaters. The most effective result is obtained through the use of different aquatic plants at the same time because the advantages of various duckweed species are integrated. Recent contemporary theory and practice of sustainable landscape design have a higher regard for the performance of nature in the remediation design process [14].

One of the leading exponents of this line of research is Viet Ngo, a Vietnamese student of engineering and art in the USA, who, from his early works, showed from the outset an interest in the environment and the land. This interest developed into research that lies between environmental and public art, and he founded a research institute, Lemna Company, that promotes the treatment of water polluted by toxic waste by means of a natural and environmentally-friendly system, using no electric power or chemical agents. Ngo became increasingly interested in creating work that would address environmental issues and merge his artistic sensibilities with problem solving. In creating Lemna, he aimed to transform wastewater treatment facilities, which are necessary pieces of infrastructure usually hidden away or disguised, into parts of the landscape. In 1990 Ngo applied his method of water treatment and purification to the Molgora River, an affluent of the Adda, in the north-west of Italy [15]. This experience was realized after some other previous projects such as the system to purify the water of Devils Lake, North Dakota, which covers an area of 36 ha and filters over 13,000 $\mathrm{m}^{3}$ of water a day. The scheme for the purification of the water supply was undertaken to improve the 
quality of the landscape and reduce the level of water pollution by fertilizers used in agriculture [16]. Ngo considers himself a multi-faceted artist who receives personal fulfillment through projects that are environmentally responsible and contribute to society. The structures designed by him are systems of water purification but look like art installations and landmarks that are capable of producing new public spaces and parks [17] (Figure 2).

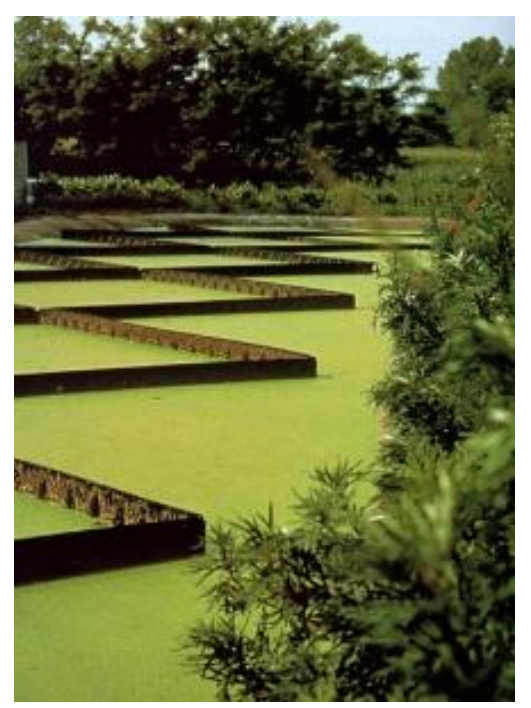

Figure 2. Viet Ngo applied his method, Lemna System, of water's treatment and purification in the Molgora River that looks like a land-art installation, Adda affluent, in north-west Italy, 1990.

The reclamation process of disturbed lands could represent an opportunity to be both a social change as well as an environment ecological compensation. Vintondale, Pennsylvania, a long-neglected 16-hectare site, had hosted both a coal mining operation and an urban landfill. Toxic orange streams and the absence of life within their banks attest to the widespread environmental problem of devastation wrought by acid mine drainage (AMD). Acid mine drainage is a mixture of highly polluting heavy metals, which regularly seeps out from the abandoned mines. Naturally, passive and active solutions for acid mine drainage are built out of sight, enclosed by a chain-link fence (Figure 3).

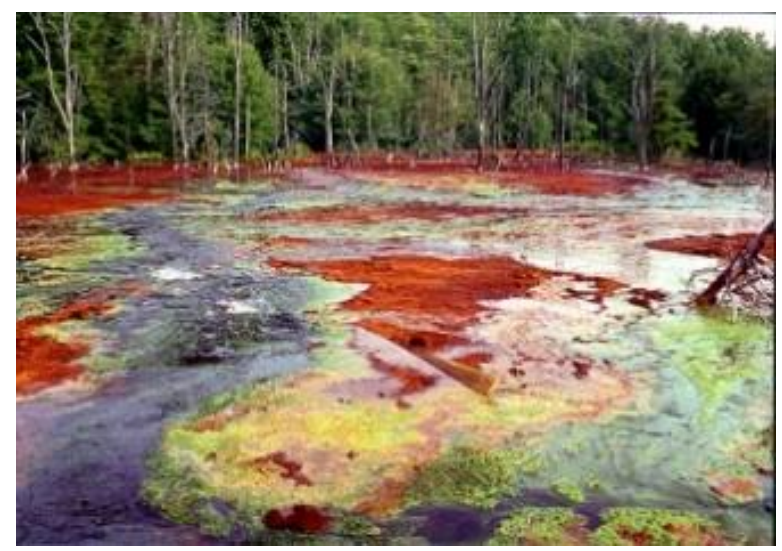

Figure 3. AMD\&ART. In Appalachia's territory, unregulated mining prior to 1977 created a huge environmental problem called Acid Mine Drainage. Inside abandoned mines, ground water reacts with pyrite and oxygen, creating sulfuric acid, which dissolves metals in the surrounding earth, mostly iron and aluminum. Vintondale, Pennsylvania, 1995-2004.

The promoter of the initiative, historian Allan Comp, imagined that the process of reclaiming this territory could be a collective experience that could involve citizens and form a civic, coexistent 
solution through the employment of art and the engagement an entire community. In 1995, he created a team in collaboration with landscape architect Julie Bargmann D.I.R.T. Studio, the environmental artist Stacy Levi, and hydrogeologist Robert Deason to envision a treatment system that would engage the landscape by creating a park that celebrated the treatment of water, rather than render that process invisible [18]. The treatment, named Testing the Waters, is a new method of designing a passive water treatment solution for acid mine drainage [19]. Rather than an engineering solution, this project both treats the water and shows the process. The Litmus Gardens, hedgerows of native trees and shrubs vivify the process of the water treatment, reflecting the color of the water as it progresses throughout the treatment's communicating basins from orange, to yellow and then to green. The project has achieved a dual objective to give the town of Vintondale a chance to reclaim its own territory and to preserve the paradox inherent in the cohabitation of natural beauty with the industrial past and to create a living solution that framed the incongruities of nature and industrial toxins: to treat the water and to show the process. Local communities, horticulture groups and community service groups were some of the members of the community to collaborate on a model redevelopment initiative for post-coal mining regions and to involve themselves through a series of neighborhood meetings and field days, tree planting, and working activities to build site furnishings and create wildlife habitats (Figure 4). The Vintondale pilot project tests the waters, building a visible sign for communities to participate in the dynamic process of applying progressive science and technology, visionary planning and policy, and celebrate heritage with a renewed landscape experience [20]. With a focus on making remediation processes visible in a new public park, the ten-year process which ended in 2004, the didactic forms of passive treatment for acid mine drainage, demonstrates the potential regeneration of neglected landscapes: resilient nature growing around a mixed palette of residual pollutants.

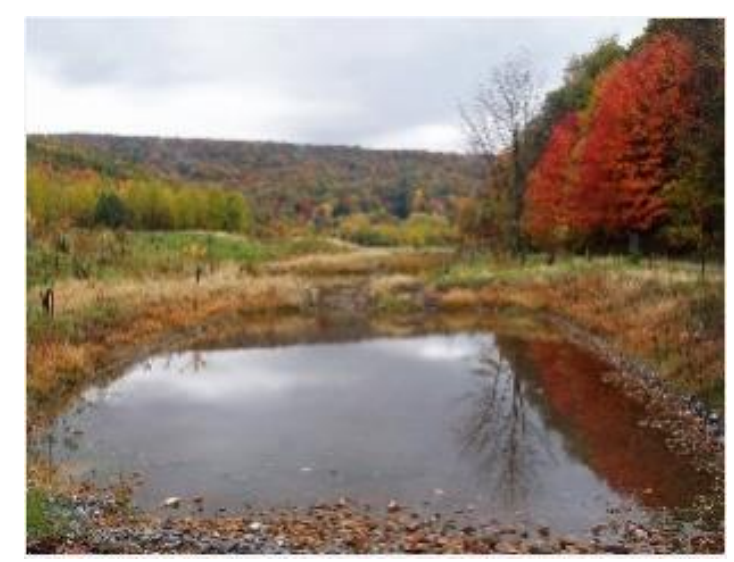

Figure 4. AMD\&ART. Acid Mine Drainage through a passive treatment system, relying on natural processes to raise the $\mathrm{pH}$ and remove the metals. This type of system has several benefits, including low overhead and maintenance costs. Passive treatment systems also provide more design opportunities, and can create new opportunities for historical, natural and scientific understanding. Vintondale, Pennsylvania, 1995-2004.

\subsection{Recovering Landscape. New Aesthetics of Ecology}

The topic of landscape restoration means a form of legacy that needs to be recovered and designed for new purposes. A deep awareness of the auxiliary disciplines and techniques is introduced into the design dimension to give substance to the formal dimension. The prolific landscape ecology and ecological restoration disciplines significantly influence landscape architecture. Forward-thinking ecological and environmental planning and landscape architectural practices, however, can diversify their scope, environmental effectiveness and enduring resilience.

In the Fresh Kills Park, Staten Island, the landscape project produced a multi-purpose process, implementing a wetlands system in order to recover the landfill site. In 2001, to take advantage of 
the potential for the adaptive end use of the Fresh Kills Landfill, the City of New York, in association with others institutions, conducted an International Design Competition to foster the development of a master plan for transforming the landfill in the Park. The goal was to attract the best talent worldwide, to generate ideas and innovative park designs that would meet the needs of the city's communities and respond to the natural and constructed history of the site. The Fresh Kills was a landfill covering 890 ha in Staten Island. The landfill opened in 1948 as a temporary landfill, but by 1955, it became the largest landfill in the world, and it remained so until its closure in 2001. At the peak of its operation, in 1986, Fresh Kills received 29,000 tons of residential waste per day (Figure 5).

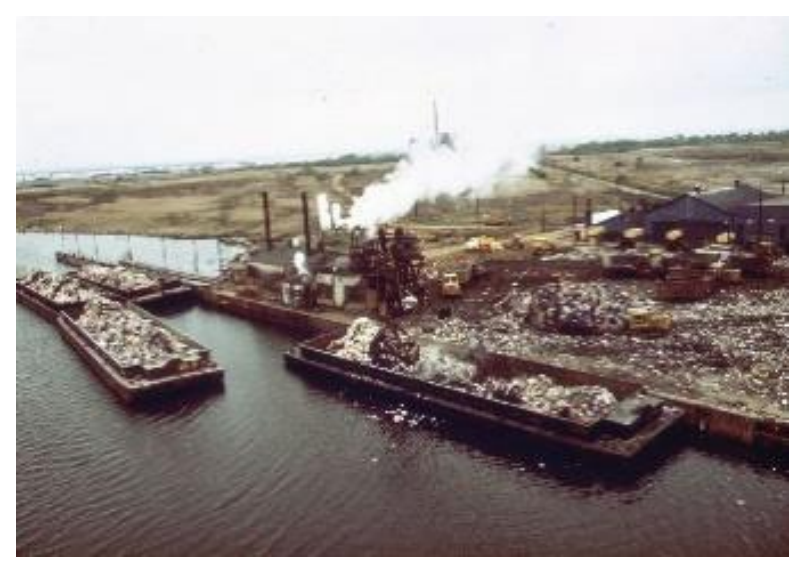

Figure 5. Fresh Kills opened in 1948 as a temporary landfill and it remained so until its closure in 2001. At the peak of its operation, in 1986, it received 29,000 tons of residential waste per day. In the picture is the landfill in 1974.

Field Operations, founded in 1999 by James Corner and Stan Allen, won the competition. The office aims to propose solutions for new public spaces based on the collaboration between new ecologies of creativity and the specific disciplines of architecture, landscape architecture, city planning, ecology and infrastructural and transport system planning [21]. The practice of ecology is understood in its broadest sense through sustainable and flexible projects that are amenable to change and to increase the amount of public space through formulation of an open matrix on which to construct alternative scenarios for the occupation and identity of the place, actively incorporating sustainable energy infrastructure. The project envisaged the transformation of the area, over $75 \%$ of which was occupied by disused industrial structures, into a large natural reserve within the urban fabric of New York, enriched by the inclusion of a variety of ecosystems.

The constitution of a nature reserve was split into four phases named seeding, infrastructure, programming and adaptation, to be implemented over a span of thirty years. In each of the four phases, the process took place in four different ways: circulation, surfaces, ecology, and program. The aims of the first phase was to recover the landscape, the original natural environment on which infrastructures and facilities, required for the different functions, which have been designed to carry out in a dynamic way, the successive second and third phases. The fourth phase conceived an extension of the third phase and consisted of the space's adaptation of variations in the programs and the utilization of park development. The project envisaged a recovering landscape process, capable of introducing three different varieties of ecosystems [22]. The first ecosystem, named threads, was based on a network of water distribution and nutrient substances for plant development; the second ecosystem, named islands, was realized by areas in which to create protected habitats for special cultivations; the third one, named mats, was a system of permeable surfaces, that regulated the erosion and the transformation of the wet disturbed soil (Figure 6). 


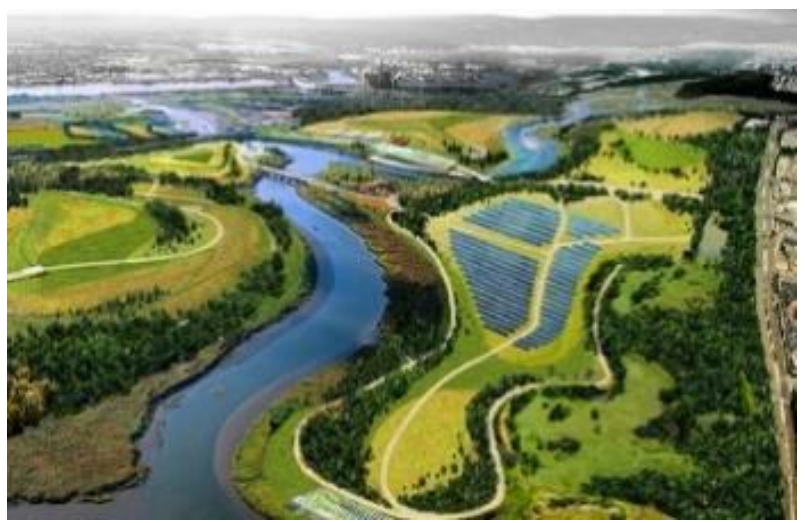

Figure 6. J. Corner Field Operations, Freshkills Park, Renowned Landscape Architecture firm. James Corner Field Operations won the 2001 competition to design the park and its vast areas over the next thirty years, actively incorporating sustainable energy infrastructure. Realization: 2010-2040 Staten Island, New York.

A pioneer of "Water Urbanism", Kongjian Yu, Turenscape Team Leader, is not only one of the most important living landscape architects, but also a keen observer of the present. His design proposals and reflections on urban planning in China are a practical-conceptual reference with which to attempt to unravel emerging questions of a planet threatened by environmental catastrophes, hydrogeological risks and water crises. In 2005, in response to calls from residents to improve a 22-ha area in a deserted shooting range used as an illegal and extremely polluted dumping ground, the government contracted landscape architecture firm Turenscape to create Qiaoyuan Wetland Park. The site was located in downtown Tianjin where the surrounding community reaches a population of nearly 300,000 inhabitants. Two original conditions of the site, the shooting area and the earth dyke on the north side, came to be an opportunity for the landscape architect (Figure 7).

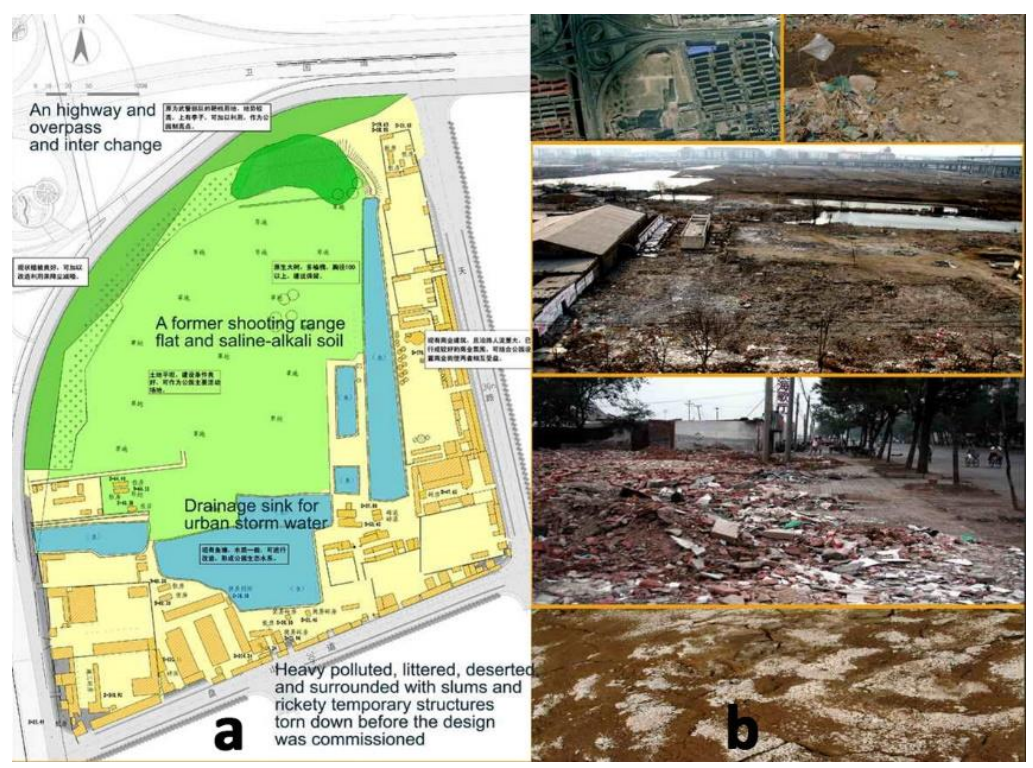

Figure 7. Kongjian Yu- Turenscape, Qiaoyuan Wetland Park. (a) Existing general masterplan, (b) the existing condition of the site: a former shooting range, shown as a garbage dump and drainage sink for urban storm water, heavy polluted with saline-alkali soil, littered, deserted and surrounded with slums and rickety temporary structures, Tianjin, 2005.

In an innovative way, the park is characterized by a micro topography through a naturalized landscape of ponds, which all vary in size and depth, where nature does all the work by collecting acid 
rainwater, neutralizing the alkaline soil, repairing the barren urban areas and finally reintroducing the structure of the native wetland that is predominant in the area. The main concepts of the QiaoYuan Park design are starting a natural process restoring the ecosystem and enabling the park to provide diversified ecosystem services to the city, realizing an ecological park with high performance and low maintenance costs [23]. Kongjian Yu uses basic elements derived from Tianjin's regional natural and cultural landscape features (Figure 8). These components range from plant materials to industrial constituents, and realize different landscapes in different seasons, making the park a complete and rich landscape experience in different moments of the year. Seasonal changes in plant species occur and integrate, successfully balancing the constraints of the urban landscape and thousands of visitors to the park each year, while preserving the integrity of the delicate native vegetation and wetland habitat by using elevated platforms extended over the habitat. This is a successful example of a design approach to reestablish natural functions and let the dynamic processes of adaptation and succession occur. Key steps in the design process included: careful planning and plant selection, experimentation with species, monitoring of progress during the construction phase as plants became established, and adjusting the design accordingly to achieve the best performance.

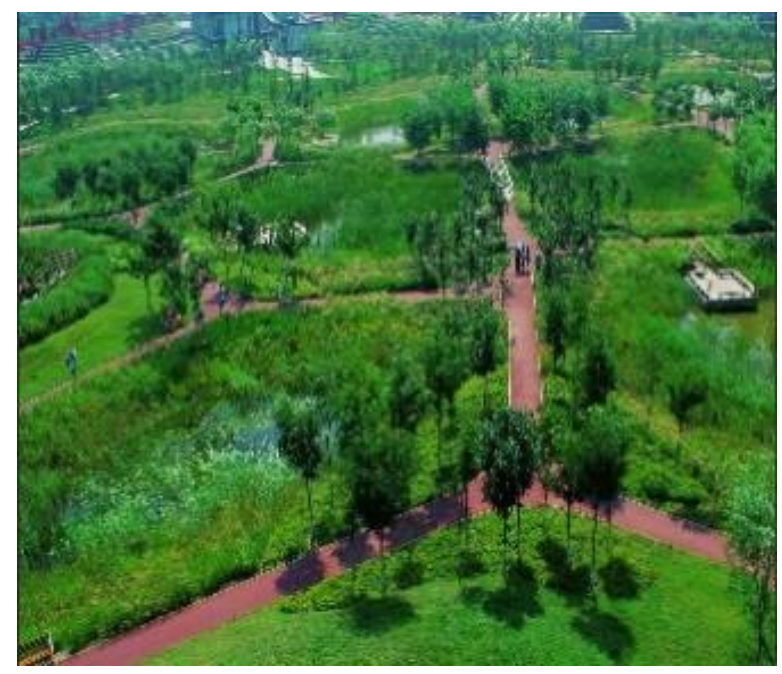

Figure 8. Shallow and seasonal water ponds occupied by diverse native communities. The design concept let nature work is inspired by regional Chinese landscapes with patchy habitats sensitive to subtle changes of water and PH values, Tianjin, 2005.

Taking as a model the founding geometries of rural landscapes, Kongjian Yu proposes works of water infrastructure with very low technology that, through adaptive behavior, recompose intermediate landscapes between cities and nature, concrete representations of the association between man and the element that more than any other generates and preserves life, water [24].

\section{Second Part: Aesthetic Experience and Environmental Ethics Transform Polluted Industrial Urban Sites into Fertile Public Ecosystems}

Soil Quality is the persistent capacity of soil to function as a living ecosystem that sustains plants, animals, and humans. This reveals the importance of managing soils in order to maintain their quality for future generations. In the design practice the consideration of it as a living ecosystem reflects a fundamental shift in the way we conceive the design of public urban space; soil is an ecosystem that provides nutrients for plant growth, absorbs and holds rainwater, filters pollutants, serves for agricultural production of better food, and provides habitat for microbes to nourish the diversify that is a necessity for ecosystem cycles.

In order to return places to their communities, soil remediation becomes pivotal in these "disturbed sites" [10], (pp. 59-86), polluted and contaminated landscapes previously used for industrial activities. 
Two paradigms stand, in the recent landscape and city history, as references for the sustainable, ecological and site-specific decisions in the biological remediation strategies of the site.

Richard Haag with the Gas Works Park in 1970 built an extraordinary contemporary paradigm where heavily polluted dirt remained in situ and through active biological processes and the passing of time became cleansed. "Haag embraced a method of soil remediation which involved the excavation of the contaminated topsoil (approximately 20,000-30,000 cubic yards) and subsequent "burial" in the mound (along with the concrete foundations, slabs, pits, supports, and miscellaneous structures) (Figure 9). Soil from the grading of the site and parking lot were spread over the site, and subsequently mixed with bio-degradable elements such as sawdust and leaves to allow air to circulate in the soil. On top of this material, treated sewage sludge, complete with oil-degrading enzymes, was placed and plowed into the soil. The increased air circulation and the sewage sludge enhanced the bacterial action within the soil, bacteria which would break down the harmful chemicals in the soil. This alternative was weighed against that of removing entirely the contaminated soil but this was cost-prohibitive. In 1997, funding became available to address the remaining contamination issues at Gas Works Park. Field studies determined that carcinogenic polynuclear aromatic hydrocarbons (PAHs), arsenic benzene and toluene as well as non-carcinogenic PAHs in the groundwater exceeded the acceptable levels. In addition, the field studies identified two areas within the park which had tar residue near the surface, and this tar and adjacent contaminated soil was removed and remediated using high temperature heating system.

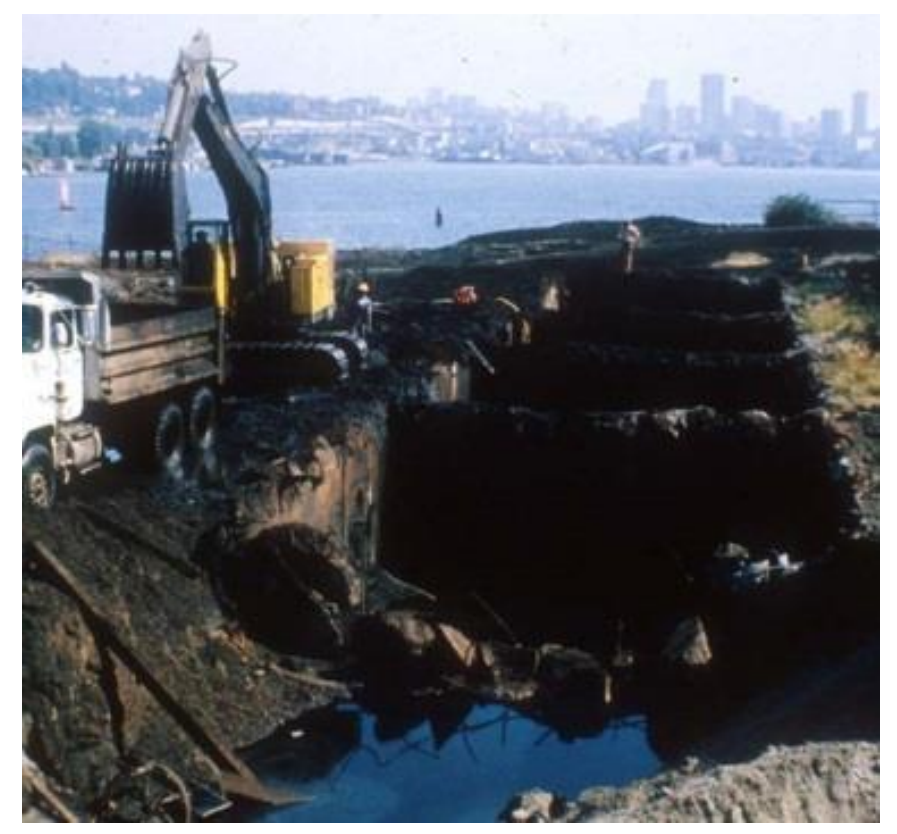

Figure 9. Richard Haag, Gas Work Park. Soil treatment on the former Gas Plant. Work on site was experimental, for the first time involving bioremediation and biodegradation of dissolved organisms present in the soil. Seattle, 1970-1975.

The cleanup plan consisted of: a protective vegetated soil cover over unpaved open areas and an air sparging and soil vapor extraction system was installed. This system consists of pumping compressed air into the saturated soil as the air moves to the surface it both oxygenates the groundwater and strips volatile organic compounds (VOC), such as benzene, from the soil. This oxygenation of the groundwater stimulates the biodegradation of dissolved hydrocarbons by native organisms present in the soil" [25]. At present, the park is completely integrated in the urban structure and is the place for open air healthy activities, sports and entertainment for citizens (Figure 10). 


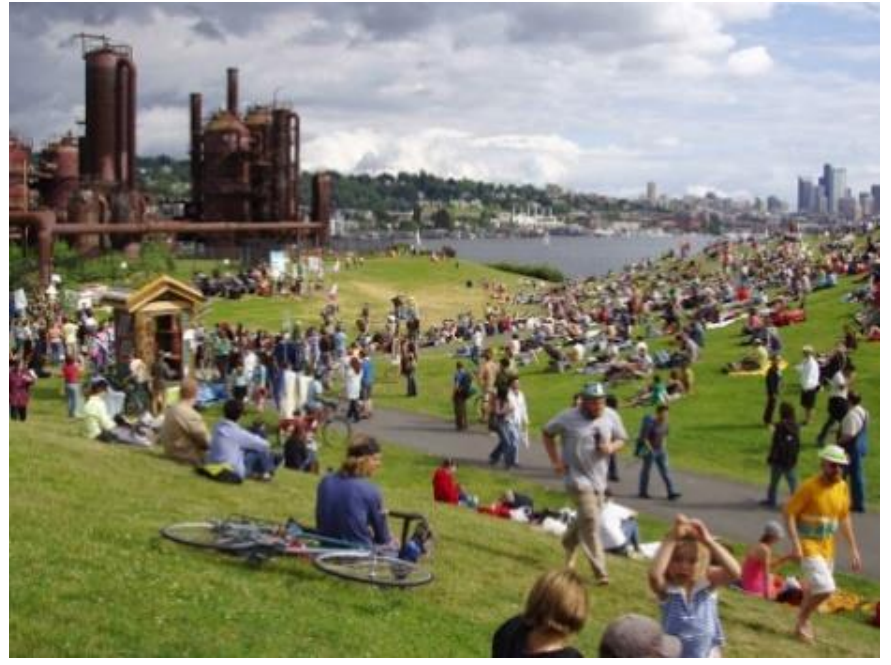

Figure 10. Richard Haag, Gas Work Park. The successful engagement of people with the former industrial site happens currently. Seattle, 1970-1975.

Peter Latz's strategy in Duisburg Nord since 1991 focused on remediation through either isolating the contaminated dirt in bunkers on site or leaving it in place; allowing it to improve quality through phytoremediation, where Plants are used to contain, degrade and eliminate contaminants in the soil through their roots, leaves and life cycles (Figure 11). In addition, the Emscher water stream improved through a series of marshes, ponds and water aeration.

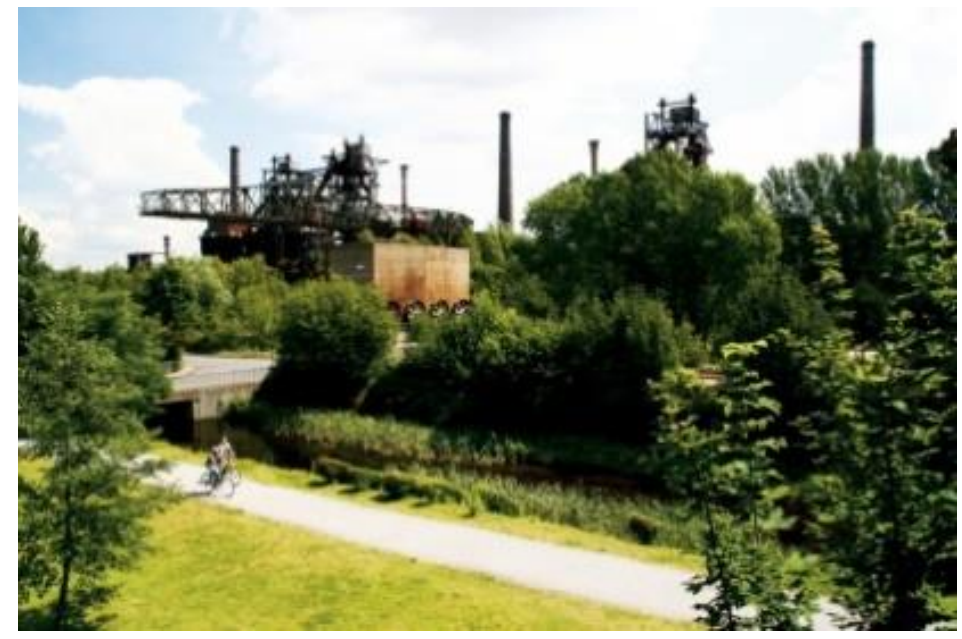

Figure 11. Latz und Partner, Landschaft Park. Peter Latz's strategy focused on remediation through either isolating the contaminated dirt in bunkers on site or leaving it in place, allowing it to improve in quality through phytoremediation, where plants are used to contain, degrade and eliminate contaminants in the soil through their roots. Duisburg Nord 1991-1998.

Through case studies in Europe focused on soil remediation, this part of the essay invites discussion about possible future scenarios, relevant theories and project responses in landscape environmental design. The essay develops a possible framework, starting from successful reality, for the conversion of brownfields into new ecosystems where water plays a fundamental role in the ground remediation processes, structuring different design strategies for contemporary public spaces in densely populated cities: 


\subsection{Hypernature as Aesthetic Experience}

In contemporary design practice, it is fundamental to build convincing aesthetic strategies to make designed forms evident, direct and capable of standing out from the ordinary. Nevertheless, definite form recognition allows the remediation process to be better perceived, considered and valued by the users. This is a fundamental passage for the design success: to go beyond form and become the base of knowledge as a cultural experience.

In the London Queen Elisabeth Olympic Park, Hargreaves Associates with a larger group of specialists found multiple solutions to remediate and restore brownfield land with on-site treatment including crushing, soil washing, bioremediation, chemical and geotechnical stabilization, restoring three kilometers of waterways as ecosystems, gaining a biodiverse habitat within the park land (Figure 12). The 247-acre park served as the central feature for the London 2012 Olympic Games, which were recognized as the "Greenest Games" in history, with the park declared the "winner of the Games" by the Mayor of London. The design synthesizes centuries of British park tradition, the reality of post-industrial brownfields, advances in sustainability and resilience thinking to create a new type of park for the 21st Century. The landscape design and the remediation action were focused around the restoration of the water and riparian habitat and ecosystems of the River Lea.

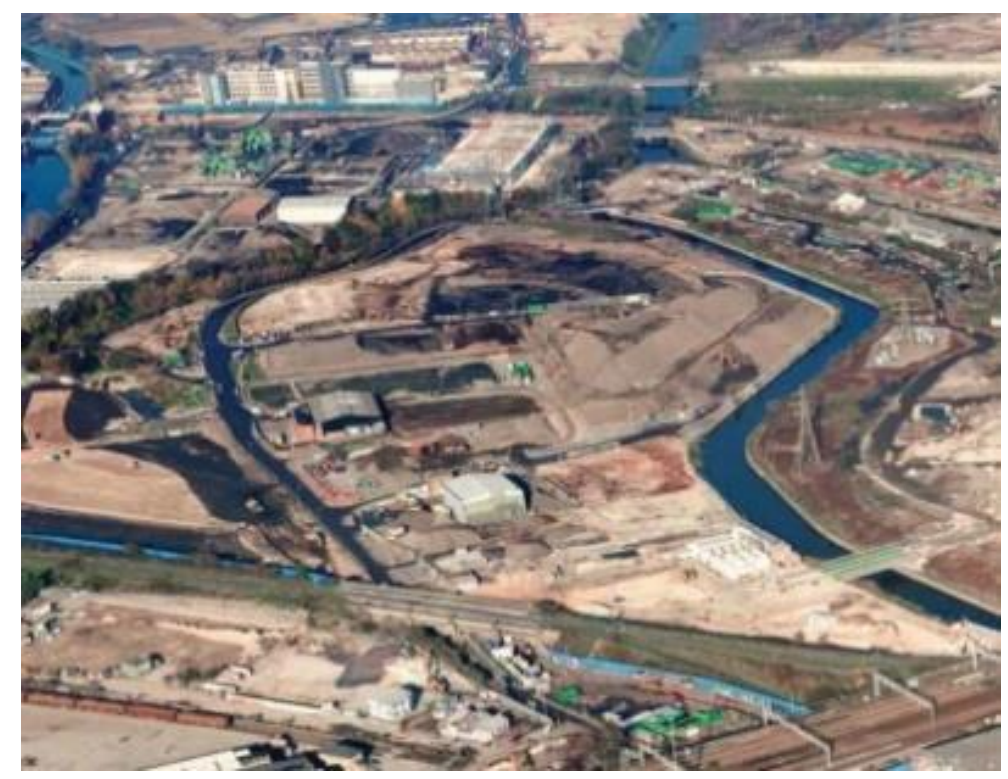

Figure 12. Hargreaves Associates, Queen Elisabeth Olympic Park. The heavily polluted soil from industrial and chemical plants also provided the bioremediation of three kilometers of waterways with biodiverse habitats within the park land. London 2007-2012.

Nevertheless, the solutions were conceived in strongly recognizable forms for users, as well being capable of reducing and managing flood risk, preparing for a changing climate to the benefit of wild life and people in the public realm. Hypernature as a design concept enhances the importance of reiterate, condensing and exaggerating the connection between forms and sustainable processes (Figure 13).

"Design should be form-full, evident and palpable, so that it draws the attention of an urban audience, the users, distracted by daily concerns of work and family, or the over stimulation of the digital world [ ... ]. The experience of beauty, a process between the senses and reason, an unfolding of awareness, is restorative. By extension, the aesthetic experience of constructed hyper-nature is transformative $[\ldots$ ] aesthetic experience can result in the appreciation of new forms of beauty that are discovered, because they reveal previously unrealized relationships between human and non-human life processes" [9], (p. 17). 


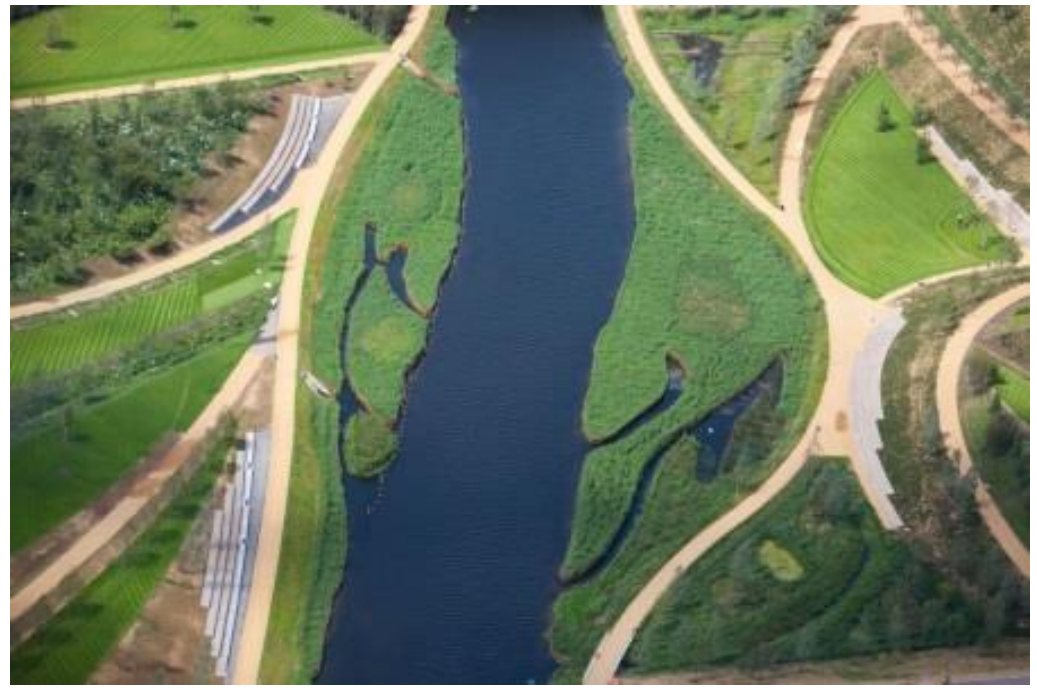

Figure 13. Hargreaves Associates, Queen Elisabeth Olympic Park. The design found multiple solutions to remediate and restore brownfield land with soil on-site treatment including crushing, soil washing, bioremediation, chemical and geotechnical stabilization. London 2007-2012.

\subsection{Public Nature as City Culture}

Public Nature embeds in the community life the importance of "Nature as a cultural resource for the City dwellers" whether it is soil, water, vegetation or fauna. Public Nature constitutes the vital core in contemporary landscape design and even more clearly in future agenda. Open space is potentially the place of democracy, which possesses the status of a living and fleeting thing. It is therefore an open source process based on change. It is the place of integration, in its condition between the public and private sphere. At the same time, it is the dimension in which Nature, in the Open City, flows and belongs to urban construction, as in ancient times. To put at the heart of any transformation the open, collective and natural space is giving it a primary role in the act of transformation. It has important consequences in the outcomes of contemporary life in cities and urban communities.

Peter Latz in the Dora Park in Turin reaffirms the aesthetic of the industrial ruins when transforming brownfields into a fluid open space system along and across the Dora River (Figure 14). "Our new conceptions $[\ldots]$ is a metamorphosis of landscape without destroying existing features, an archetypal dialogue between the tame and the wild. Specific architecture for specific uses does not need to be built. The imagination lets the existing ones be re-interpreted and used in new ways. Artefacts can develop natural processes in derelict surroundings according to ecological rules started and maintained by technological processes. It is the idea of making time visible", [26].

The river is given back to the citizens, despite the current and unsolved discussion about contaminated water with a heavy quantity of hexavalent chromium flowing through the park. Natural bioremediation processes of contaminated soil are integrated by Latz's design within urban life, becoming cultural knowledge for people.

Most recently Latz und Partner have been working on polluted soil remediation from arsenic contamination of the Spree Park in Berlin, a former D.D.R. amusement park, along the river Spree in the Plänterwald (timber forest) close to the city center (Figure 15). Latz is a world pioneer in soil remediation, focusing on simple and effective natural techniques which generate circular effects on the care of places as well as in the long run on the improvement of human habits with the aim to unite through design, art, culture and nature. 


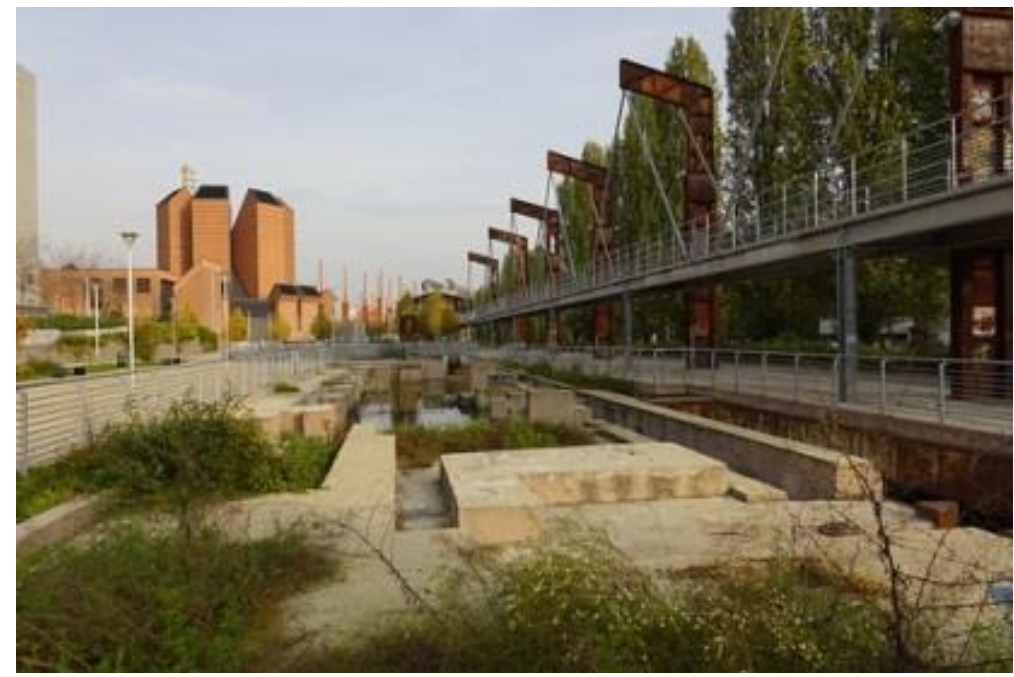

Figure 14. Latz und Partner, Dora River Park. Natural bioremediation processes of contaminated soil are integrated within urban life. Turin 2004-2012.

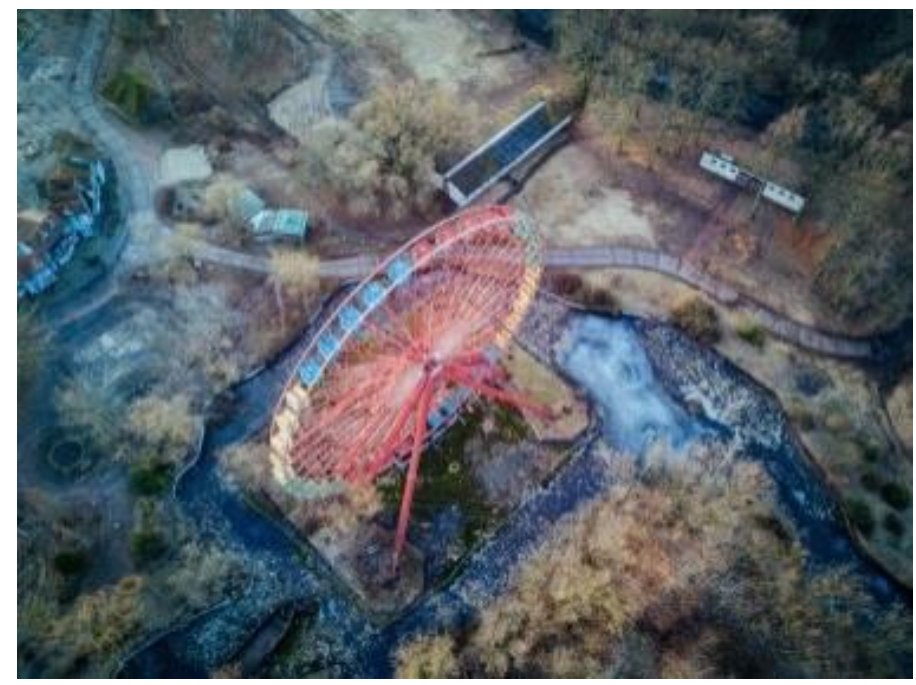

Figure 15. Latz und Partner, Plänterwald in the Spree Park. The polluted soil remediation from arsenic contamination along the river is focused on simple and effective natural techniques. On-going in Berlin.

\subsection{Operative Nature Sustains Environmental Ethics}

Nature operates as the remedy in soil polluted sites. Operative Nature stands as an active process, responsible for positive changes in the environmental quality of the public space. Design sustains the Ethical approach from an environmental and a cultural point of view. Users, through the project, become more and more aware of the environmental values beyond form. Operative Nature in urban spaces values the natural cycles in contemporary forms improving the ecosystems' quality and the built space.

The selected design paradigms of existing fertile public soil ecosystems embed the necessary conjunction between the aesthetic experience (which goes beyond the appearance of forms), the scientific research (ecological) and ethical responsibility.

The Cuulturpark Westgasfabrieck, in Amsterdam, is a new public park, designed by Kathryn Gustafson, on the heavily contaminated site of an old gas factory.

The soil pollution problem had to be addressed and the solution could only come from an ecological perspective. Contaminated soil could not be removed and transported elsewhere, where it would have caused more damage. Consequently, it was decided to balance the excavation and carry-over volumes: 
to bring new soil to replace the polluted soil, to maintain the existing soil levels around the buildings and to create a new undulating soil with excess material. The placement of the contaminated soil on-site (with the presence of heavy metals and benzene) was the best environmentally economical oriented decision (Figure 16).

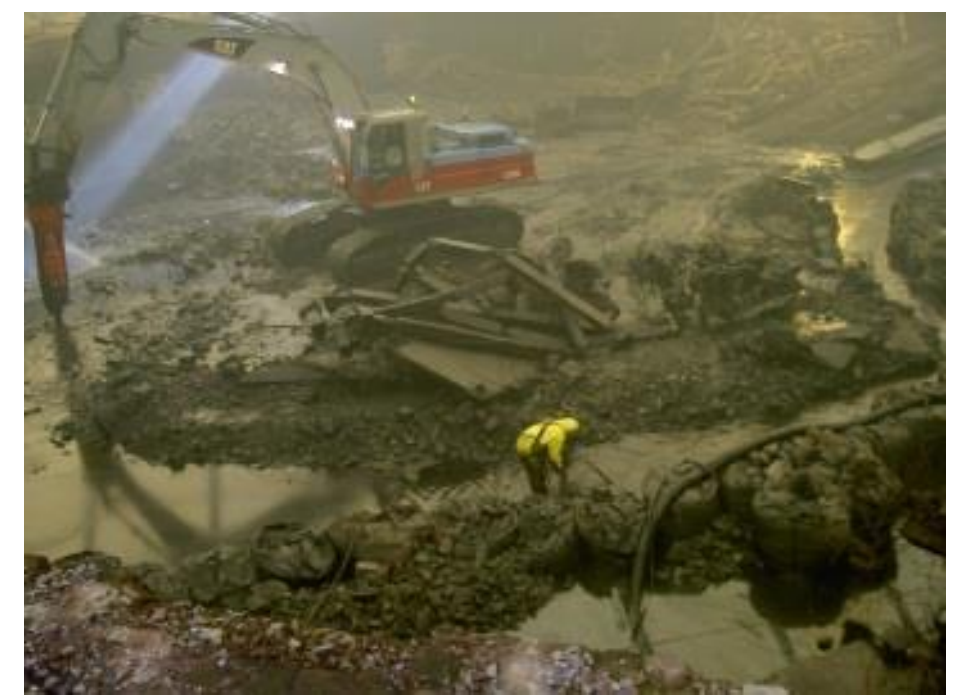

Figure 16. Gustafson, Porter and Bowman, Cuulturpark Westgasfabrieck. A new public park designed on the heavily contaminated gas factory site. Contaminated soil could not be removed and transported elsewhere. The placement of the contaminated soil on-site was the best environmentally economical oriented decision. 2006 Amsterdam.

The remediation process required the presence and the permanence of rainfall infiltration into the soil to maintain current water level in order to preserve the wooden foundation of the historical buildings. So, to preserve the existing ground permeability, the capping solution was suitable only for the impermeable paved areas and the cut and fill process was selected. Moreover as water was cleaned and protected with a barrier from the polluted soil water table, cleansed water started to assume different forms with the shaping of the ground plain: canals, streams, small lakes, splashing fountains and rainwater pools (Figure 17). The water in the park is purified, processed, and stored while the cleansed ground plane has been designed to enrich the visitors' sensory experience, inviting people to engage in water activities and to learn from natural processes about soil remediation and the temporality of landscape design (Figure 18).

These themes, presented through built contemporary paradigms, arise as a vision of reconciliation, between the city and exploited soil through natural processes, between the sciences and the arts, in an action of care and responsibility for the present and the future of our cities. This attitude generates virtuous evolutions of sociality, respect and care for places and the acquisition of environmental consciousness by the inhabitants. They acquire, through the learning of sustainable landscape design, its forms and the manifestation of natural processes, the knowledge of the finiteness of the resources and the value of Environmental Ethics in the design of forms.

Landscape architecture has a pivotal role in the coexistence of beauty and environmental issues in the interventions. Landscape architecture deeply responds to the need of the present time as it addresses: ecology, remediation, cleansing, environmental infrastructure, social sustainability, healthy and productive landscapes. 


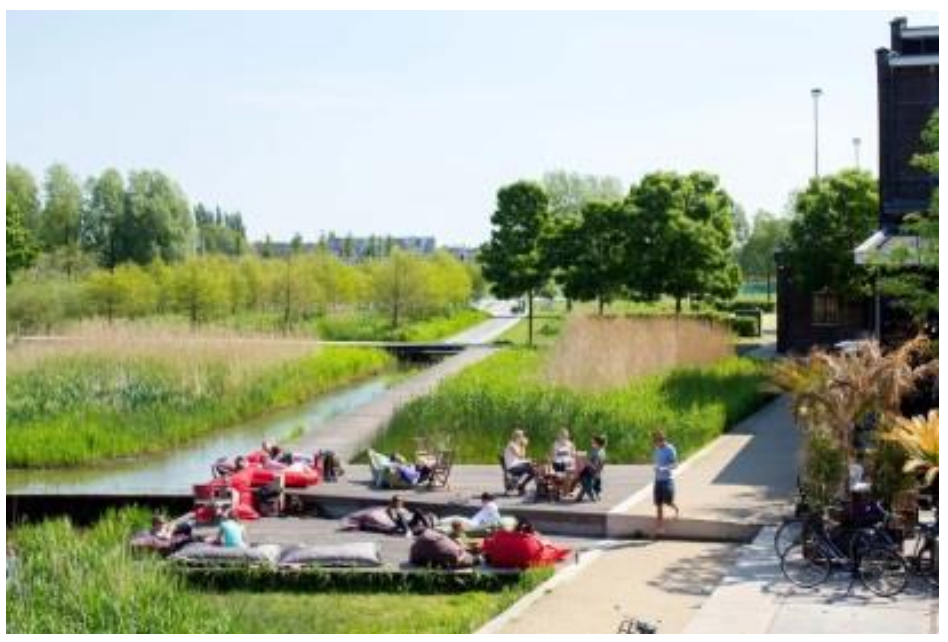

Figure 17. Gustafson, Porter and Bowman, Cuulturpark Westgasfabrieck. Water was cleaned and protected with a barrier from the polluted soil water table, cleansed water started to assume different forms with the shaping of the ground plain: canals, streams, small lakes, splashing fountains and rainwater pools. 2006 Amsterdam.

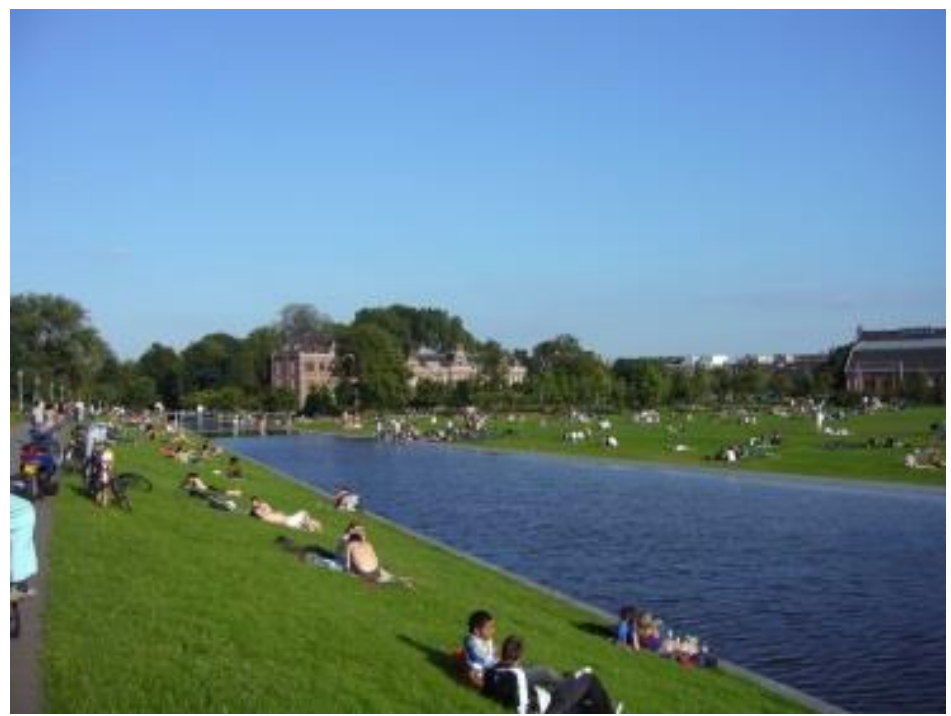

Figure 18. Gustafson, Porter and Bowman, Cuulturpark Westgasfabrieck. The water is purified, processed, and stored and it enriches the visitors' sensory experience, inviting people to engage in water activities and to learn from natural processes about soil remediation and the history of the site. 2006 Amsterdam.

\section{Third Part: Soil Design as a Space of Resilience to over Flow: New Unstable Urban Landscapes}

Climate change and exceptional events of flooding and atmospheric precipitation have profound effects on soil quality. Erosion, pollution due to clogging of water management systems, contamination due to flooding, damage due to soil sealing, are the most evident effects of these mutations.

These phenomena are now increasing in number and intensity and the urban environment is certainly a scenario particularly frail to these events, and is exposed to produce risks. From a European Environment Agency (EEA) document: "A wider literature review suggests that heavy precipitation events have become more intense and more frequent in Europe on average, but there are important differences across regions, seasons, time periods, heavy precipitation indices and underlying datasets. A recent study has shown that the number of days with very heavy precipitation over Europe has increased on average by about 45\% (for the period 1981-2013 compared with 1951-1980). 
Studies generally agree that heavy precipitation has become more intense in northern and north-eastern Europe since the 1950s, even though not all changes are statistically significant. Different studies and indices show diverging trends for south-western and southern Europe" [27] (p. 8).

The technique generally used to deal with these situations was the construction of lamination tanks or expansion tanks that worked to accommodate large quantities of water in order to avoid the disposal system clogging. The idea was to store rainwater in these buffer areas to postpone their disposal until the drainage system recovered its seating capacity. This implied the belief that water was an unlimited resource, while today these systems are surpassed by a design that starts from the principle of preserving and using rainwater. The prerequisite of this approach is the separation of white water from waste water which allows the use of rainwater without it being contaminated by sewage water and prevents the sudden flow of rainwater from surpassing the capacity of the purifiers, producing uncontrolled spills.

\subsection{The New Trends}

The turning point, in the context of a changed attitude towards natural resources, is mainly due to the concept of landscape approach as a method [28] (pp. 9-11), and of integrated design brought forward in the last decades in American studies on landscape and in the many contributions of different disciplines. This principle, starting from McHarg [8], continuing with the development of Corner on Landscape Urbanism [21], and up to Urban Ecological Design [29], spreads the seeds of a new approach to the design of the contemporary city in an ecological vision. This vision-readily accepted in northern Europe first, with consolidated Danish and Dutch experiences from Jan Gehl and Aldo Van Eyck, up to the latest West8 or SLA architectural labs, and after in France by the actors and followers of the Versailles school: Corajoud [30], Clement e Donadieu [31]—has been elaborated upon within the European landscape culture, developing an original framework due to the long tradition in urban planning and public spaces.

In recent decades, therefore, there has been a progressive change of direction [32]. In managing the relationship between the city and water instead of simply protecting the territory from floods or facing the sudden rains trying to free the soil of the large amount of rainwater, strategies are experimented to allocate the presence of this water on the ground surface and then release it in the soil when useful. Managing the overflow through flow regulation and rainwater conservation, allows their reuse for climate change effect mitigation and in the treatment of heat islands. The long-standing attention paid to the presence of plants in the urban landscape and to the care of the public space seem to have had a favorable evolution today in the contamination with these trends and with the most recent studies for a sustainable city $[33,34]$.

It is only by introducing and multiplying ecosystem services in the urban fabric that we can improve the urban condition but, at the same time, it is not only by bringing nature back to the city that a sustainable city is built: it is above all by reconnecting the city with its natural context, its original landscape context [35]. It is therefore not just a matter of greening cities, of strengthening ecological networks or of designing gardens, but action is to be taken to insert real fragments of nature-efficient ecosystems-into the urban fabric. In this way, while previously limited in parks, nature spreads now in the urban fabric with green and blue ramifications and nets favorable to the circulation of animal and vegetable species. When building biological corridors, maintaining areas in hay, reconstructing wetlands, a strict delimitation between city and nature is no longer applicable at the scale of the city.

A new water management strategy is therefore congruent with this different vision of the relationship between city and nature. Water and the related soil projects are essential components of context-based projects because they use existing resources that would otherwise be dispersed and, by introducing the time variable with the creation of adaptive landscapes, they allow the planning of an incremental evolution of places. This is the basis for next generation landscape urbanism [30].

The project of wet or water sensitive landscapes is an essential tool for a sustainable city and for the daily as well as for the exceptional management of events related to overflow; it is a project that 
expresses itself through the soil project, proposing adaptive landscapes, which have the ability to retain and conserve water, to act as a porous substrate, to manage rainwater and flooding, transforming them from risk factors to resources.

Two domains of a different relationship between city and water:

1. The management of floods with measures to minimize the impacts of rising water on the habitat.

2. The management of rainwater by giving it back the role of a resource.

In each of the two cases it is a question of accepting the issued water and, rather than rejecting it, keeping and it in place.

\subsection{Flood Management to Minimize the Impacts of Rising Water on the Habitat}

Flood management adopting measures to minimize the impacts of rising water on the habitat in new projects implies design choices and the analysis of the acceptability of their degree of risk. As the Urban Strategy Projects Observation Platform (POPSU) document states: "urbanization of wetlands is a complex line of thought" which must seek to bring harmony "between risk prevention plans that are part of an objective of protection of property and people and sustainable urban and landscape development" [36].

As far as new urban projects are concerned, the main theme is to ensure on site risk management by designing urban, architectural and landscape systems that, through the soil project, integrate water into the urban organization. HafenCity in Hamburg [37] is perhaps one of the best-known cases but, for other aspects, it appears a less innovative project. The city rises and defends itself from the water; the new neighborhood that connects the city with its river has been organized on different levels to ensure at the same time defense from floods and access to the river by building a city with a heightened urbanity. On the river there is a series of floating elements that absorb the daily trend of the tides which varies about three meters. These floating piers are places for walking and for bringing boats into the city; higher up is the level of the old dock warehouses where today there are cycle paths and long pedestrian paths at sea; three meters higher still, there are only the entrances to the houses, the streets and the bridges; and finally, even higher up, a system of walkways connecting the new buildings which most of the shops overlook (Figure 19).

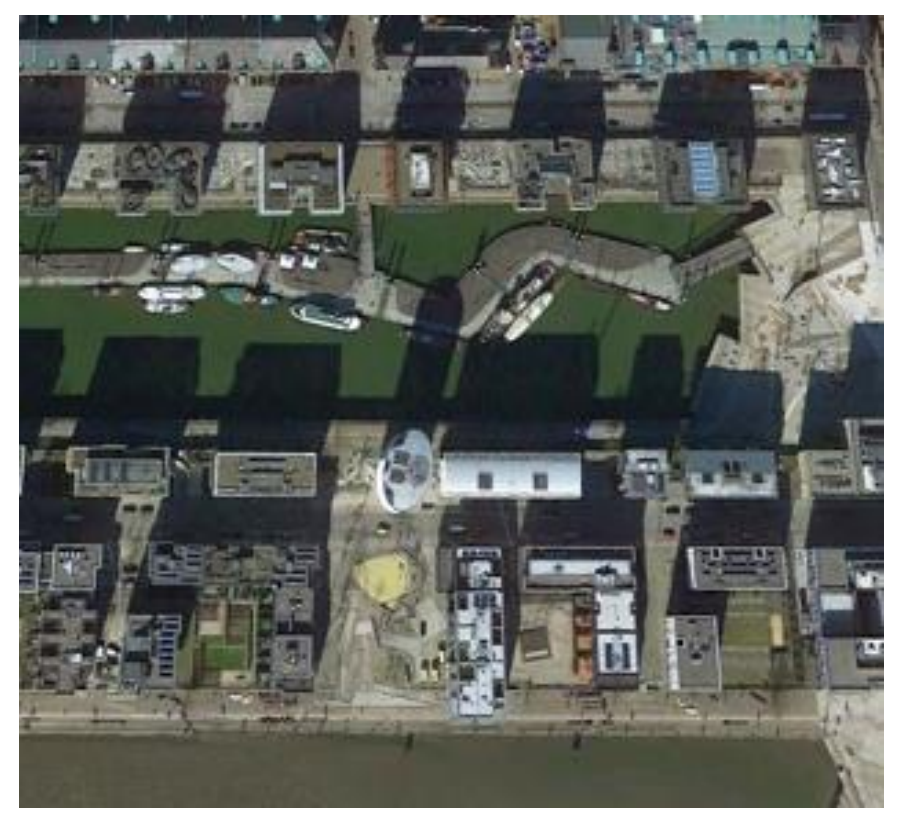

Figure 19. Hafencity: the floating piers; higher up, the level of the old docks where today there are cycle paths and long pedestrian paths at sea; three meters higher still, the entrances to the houses, the streets and the bridges; even higher up, a system of walkways connecting the new buildings. 
Noteworthy but in countertrend is the fact that vegetation has a very marginal or no role at all to play and therefore the relationship with water is essentially delegated to its mineral parts of the public space that protect and return excess water to the river. If HafenCity is well known, the Hammarby district in Stockholm is now a reference point for a sustainable city design. Designed in continuity with the pre-existing environmental system (woods and lake), the new district recovers the riparian areas, purifies the waters of the lake with phyto-depuration systems and builds a network of canals and green corridors for rainwater that crosses private and public spaces of the neighborhood and connects both the woods and lake ecosystems (Figure 20).

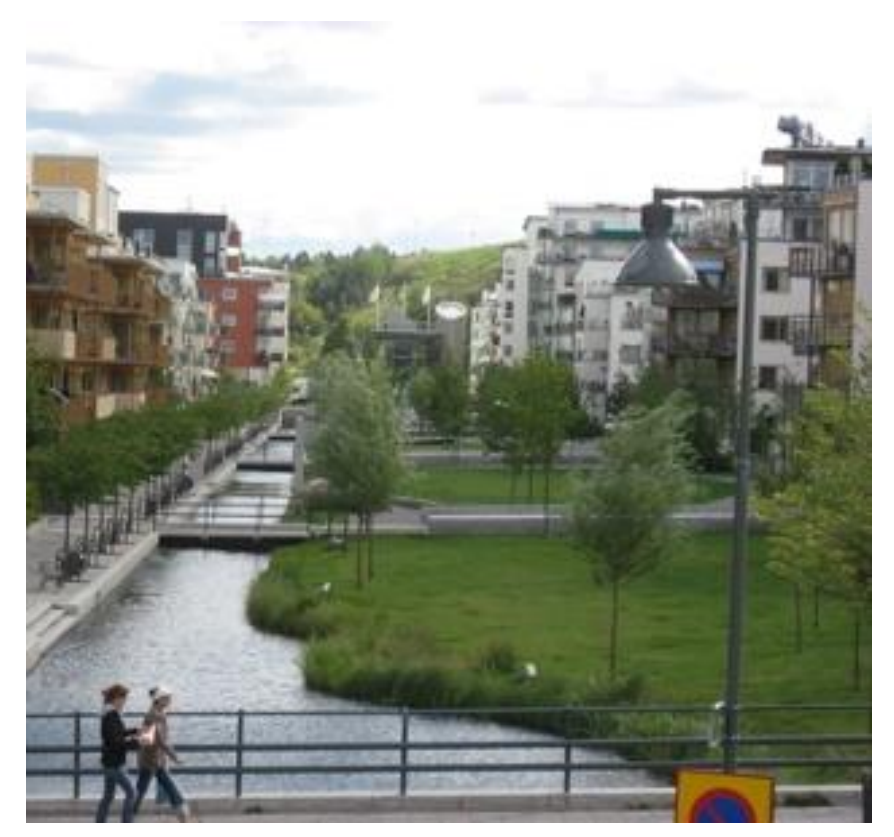

Figure 20. Hammarby: the new district recovers the riparian areas, purifies the waters of the lake with phyto-depuration systems and builds a network of canals and green corridors for rainwater that crosses private and public spaces of the neighborhood and connects both the woods and lake ecosystems.

In the same trend, is the project to transform the city of Lodz [38] into a Water Sensitive City [39]. Most of Lodz's urban waterways were transformed into underground canals in the past; this, combined with the high sealing of the soils, has exposed the city to numerous floods during the recent violent storms having numerous the consequences for the soil and the water system. As part of the European program Sustainable Water Management Improves Tomorrows Cities Health (SWITCH), a strategy for adapting the city to water has been implemented, based on the principle of green and blue networks. Urban-scale initiatives have been planned to recover the waterways and revitalize the riparian areas, to create green spaces and corridors to collect and manage rainwater, to condition urban planning to the system of green and blue networks (Figure 21). Currently, in this context, there is a pilot project and an integrated approach to design led by a team, where all the actors involved in the management of water resources and ecosystem services are represented and have been carried out.

The urban project for Vitry gare de Seine by Germe \& Jam in France along the Seine is more radical in building a water-resilient environment. It has as reference the Flood of One Hundred Years and the issue of flooding risk is at the center of the design of the public space and the urban fabric. (Figures 22 and 23). In Vitry, an artificial floor consisting of a network of elevated paths connected by walkways allows the connection of urban services and the entrances of residential buildings in the event of an extraordinary flood, while public spaces are designed to adjust to ordinary floods and violent rains. 


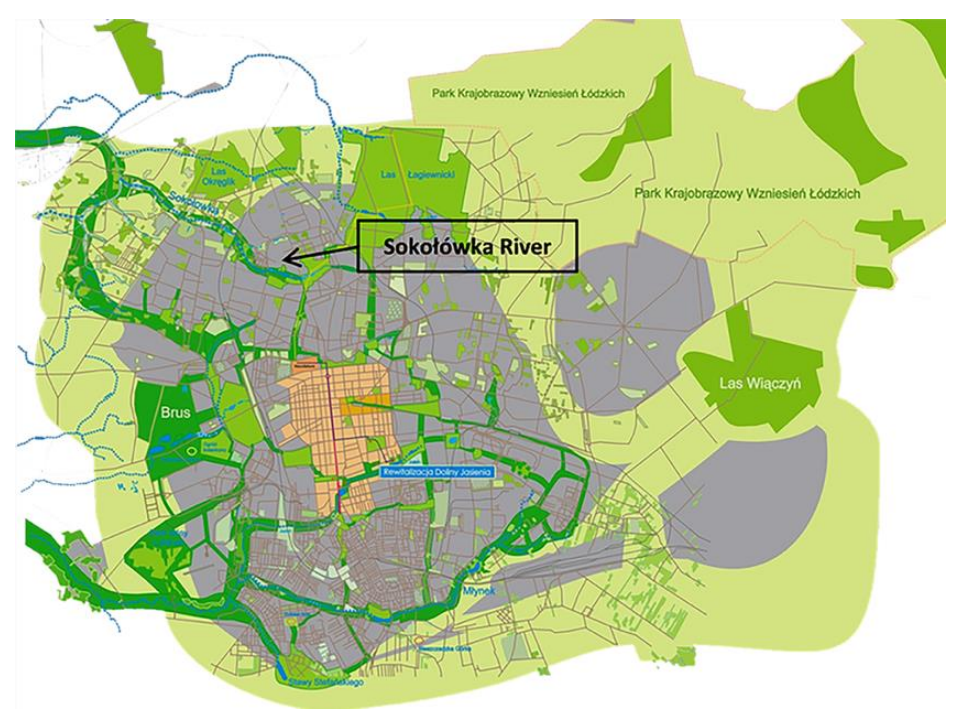

Figure 21. Lodz: urban-scale initiatives have been planned to recover the waterways and revitalize the riparian areas, to create green spaces and corridors to collect and manage rainwater, to condition urban planning to the system of green and blue networks.
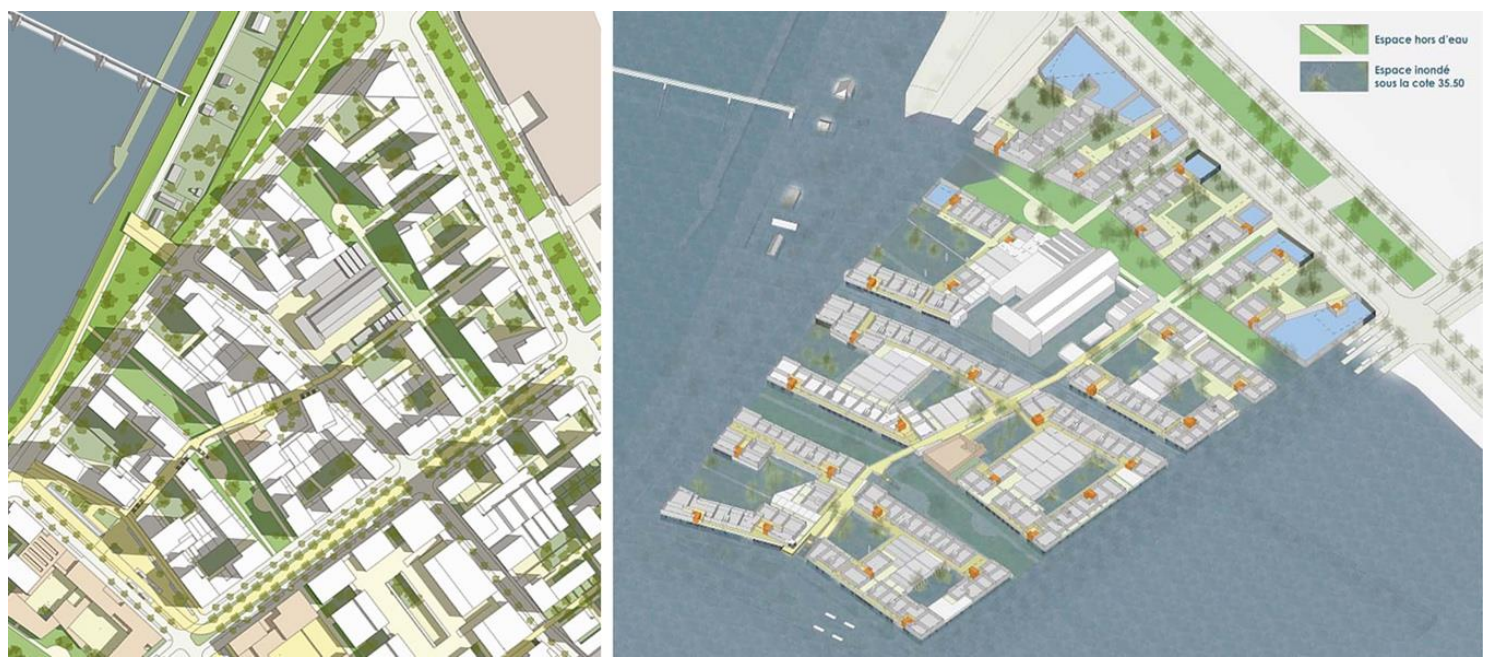

Figure 22. Vitry: the neighborhood project (left) and the accessibility during the flood (right). (C) Germe\&Jam.

The interesting element of this project is that by allowing the water to expand in the gardens and under the buildings, Germe \& Jam managed to avoid the construction of blind walls at the urban routes level as happened for instance in Hafencity. The network of elevated paths can also be used by service vehicles in order to allow, in the event of a flood, an organized and calm removal of the inhabitants. 


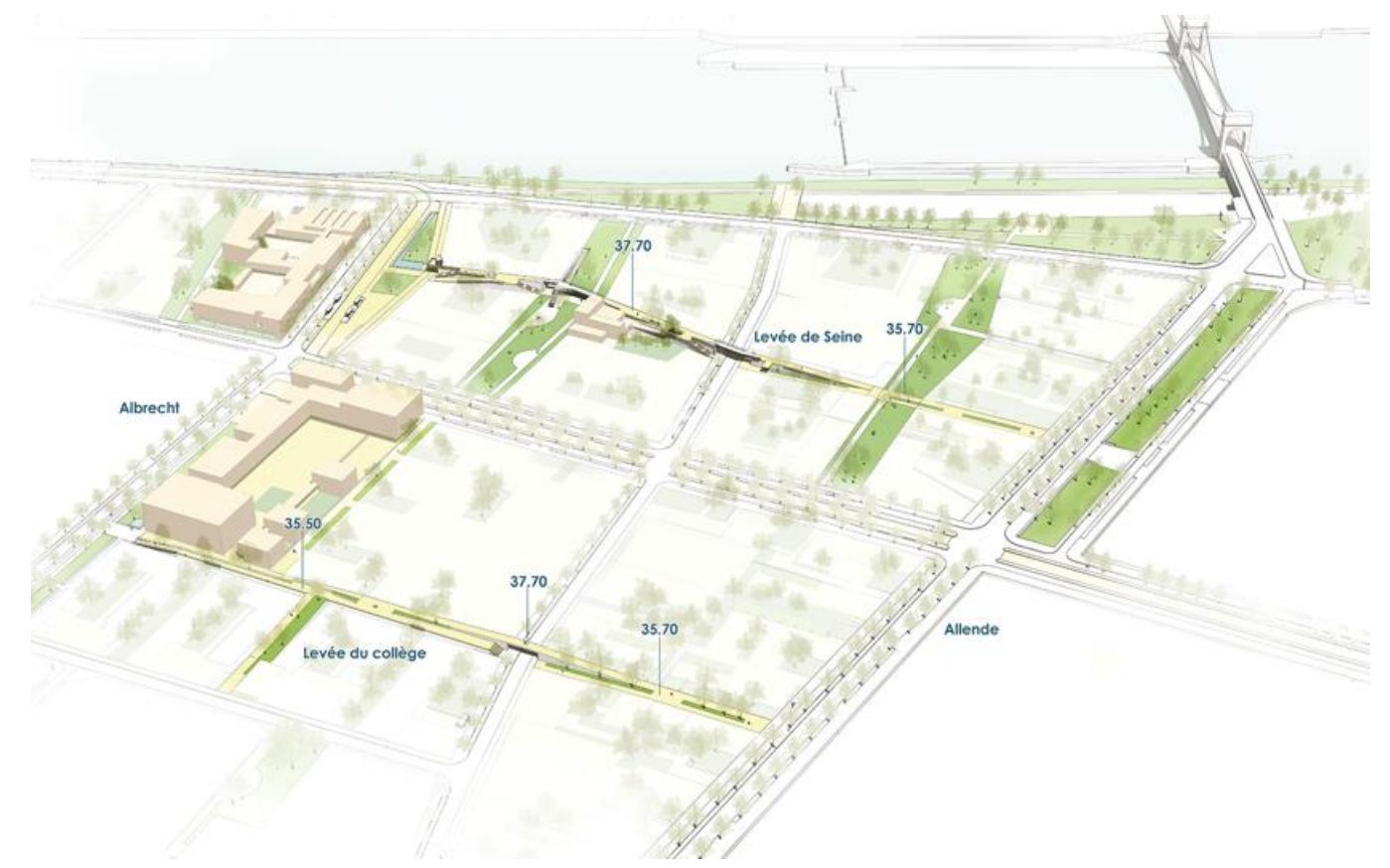

Figure 23. Vitry: a network of elevated paths connected by walkways allows the connection of urban services and entrances of residential buildings in the event of an extraordinary flood, while public spaces are designed to adjust to ordinary floods and violent rains. C) Germe\&Jam.

\subsection{The Management of Rainwater Giving Them Back the Role of Resource}

There are also very innovative interventions in the domain of the rainwater management; previously considered as something to be disposed of, today rainwater is transformed into a resource, both in "normal" and in exceptional conditions. A resource to be retained and organized by capitalizing upon it, and then to be used in irrigation, in mitigating the effects of climate change, and in the treatment of urban heat islands [40]. The number of innovative projects is increasing and the majority are oriented towards using the urban soil surface for the temporary collection of water. The water collected, when possible, is transformed into a temporary leisure resource and, at the same time, providing a careful filtering capacity and a permeability of the soils, can be used for watering or slowly released into nature. There are two types of projects: places with a prevalence of plants, parks or natural areas integrated into the urban fabrics which, in the soil and vegetation arrangement and in its design and use, integrate temporarily humid landscapes, and small-sized mineral places, squares, capable of holding rainwater, integrating the overflow with the creation of accessible pools and fountains. In the first group are the Urbanwater Parc des Docks in Saint Ouen, the Agence Ter's Parc Trapeze in Boulogne Billancourt, and the landscape project for the new Rives de la Haute Deûle district of the atelier de paysage Bruel Delmar.

In the Parc des Docks the rainwater of the surrounding neighborhood is collected and held in the open by a system of depressions and reservoirs where it is treated by means of a plant filtration device. In the absence of rain these green spaces have a landscape function, and, in case of rain, they are animated by the variability of the water, water used to irrigate the park and vegetable gardens. Moreover, the Trapéze Park in Boulogne Billancourt is at the heart of the district's rainwater management system. The permeability of its soils and the storage of water in hollow gardens filters all rainwater which is then partially recovered in a basin to be reused for irrigation (Figure 24). This water management system allows for a great diversity of plants and therefore a very differentiated management of space. The park is a true ecological niche between the river and the green spaces of the district and is designed to be used even in situations of great overflow (Figure 25). 


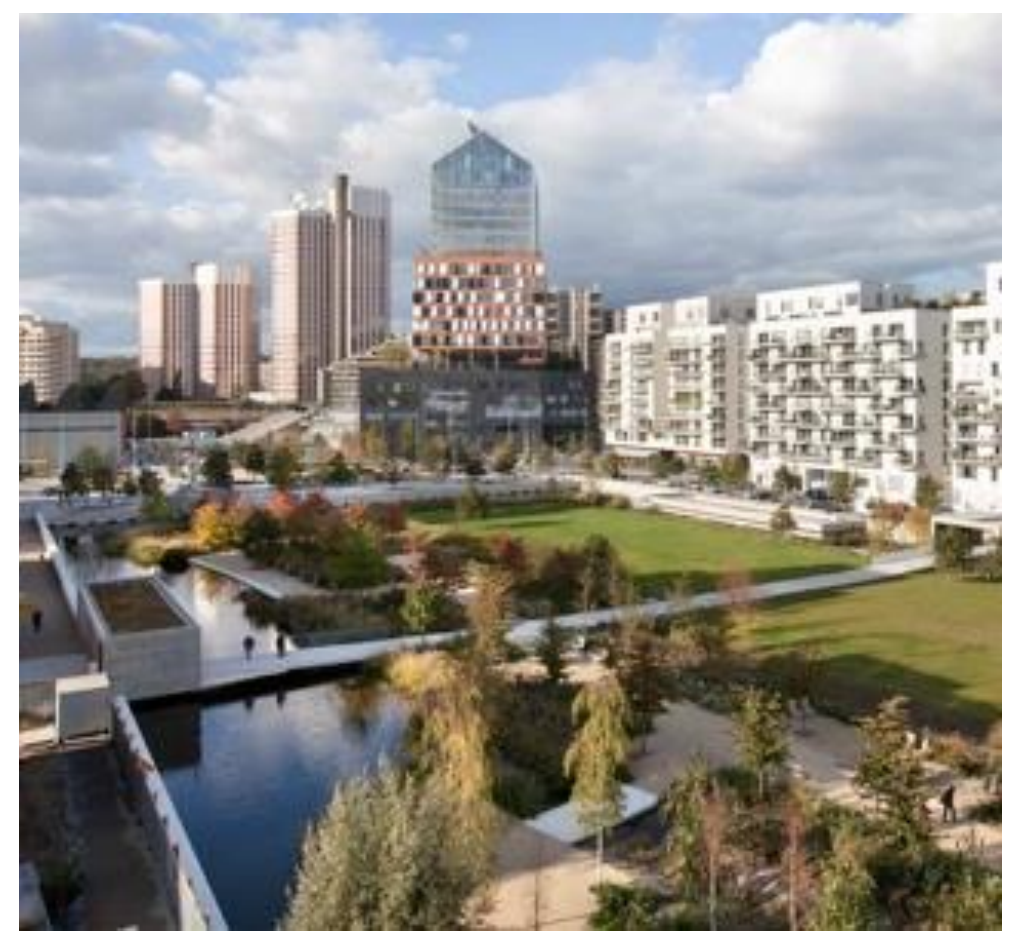

Figure 24. Trapéze park in Boulogne Billancourt is at the heart of the district's rainwater management system. The permeability of its soils and the storage of water in hollow gardens filters all rainwater which is then partially recovered in a basin to be reused for irrigation.

The landscape project for the Rives de la Haute Deûle district is based on local rainfall. Its fulcrum is an aquatic garden fed with the rainwater falling on roofs, roads and public spaces. The water flows first into the small valleys that border the islets, then into larger canals and finally arrives purified in the aquatic garden which is sized based on rainfall but also acts as a catchment area in case of floods.

Always aimed at the collection and conservation of rainwater, the second group of realizations are smaller-sized, punctual interventions where-as it happens for Tåsinge Square and St. Kiens square or Hans Tavens park of SLA in Copenhagen-the public space is a changing artificial landscape. In these projects, the shape of the mineral soil is deformed to hold and conserve excess rainwater in accessible pools and fountains which, in the absence of rain, become part of the mineral public space again, combining the construction of a functionally resilient landscape with the creation of new spaces for leisure.

These projects are the intelligent manifesto of the felicitous combination of good soil and water resource management, the mending of the urban fabric and landscape context, and the quality of the public space. In this context the theme of overflow management is an integral part of the urban planning and organization, and the urban fabric is able to absorb extreme natural events without being damaged. These interventions are representative of the various knowledge bases in the field, from which it is clear that the projects in Northern Europe and the first French projects have treated rainwater with often multifunctional works mainly aimed at protecting the city from water. This trend-especially in France thanks to the new water law that imposes a very strict limit on the elimination of rainwater-provides a lot of space for its storage in the city. Surfaces found in the public space which are, however, returned to the city in the form of changing wet landscapes. One of the effects of the management of rainwater on the surface is therefore the slow change of urban landscapes, important from the point of view of the ecosystem, as something perhaps to be monitored carefully to avoid the wrong homologation of urban spaces. 


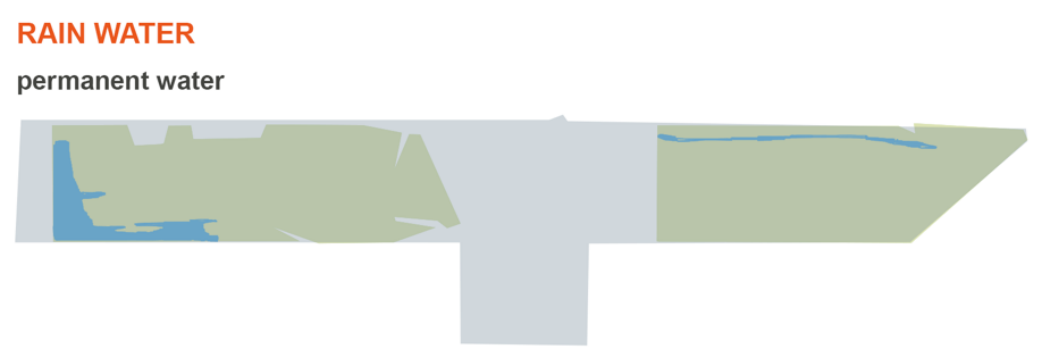

great storm

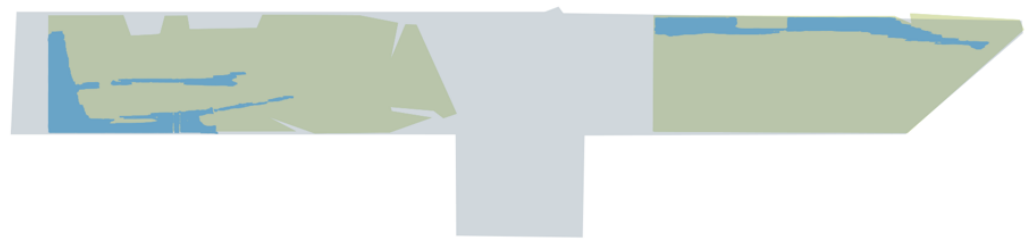

two years flood

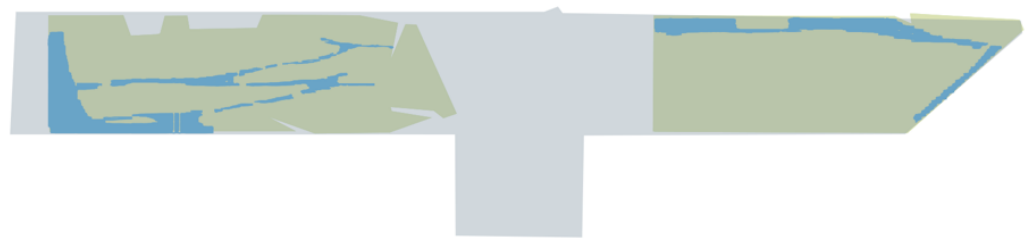

ten years flood

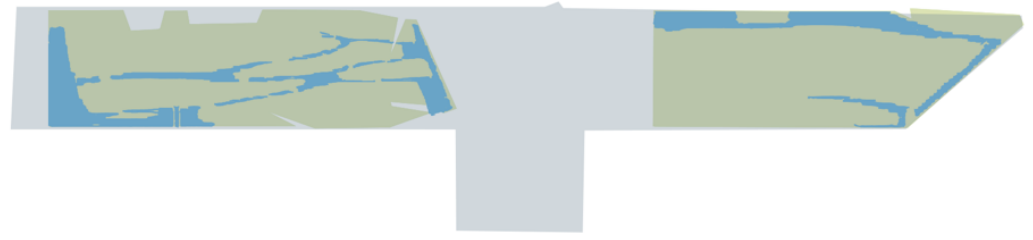

FLOOD

flood

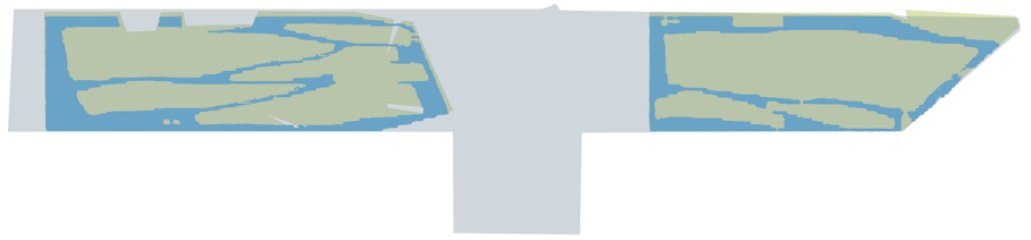

Figure 25. Trapéze park: different levels of rainwater and flood.

\section{Discussion}

Due to environmental disasters, resources exploitation, loss in biodiversity and fast climate change, which are largely caused by human action, the importance of healthy natural environments has increased. Paradoxically, waste and pollution, especially in the case of wet soil, can be potential resources for the well-being of the environment in which we live. The prolific landscape ecology and ecological restoration disciplines significantly influence landscape architecture practice and theory. Forward-thinking ecological and environmental planning and landscape architectural practices, however, can diversify their scope, environmental effectiveness and enduring resilience.

The selected projects of this essay are exemplary cases of interventions on degraded—or at risk of degradation-soils that have managed to reinforce the ecosystem services and transform those places into places for the community. In three different types of places: former landfills, industrial sites, and urban locations threatened by overflow, the strategic design of wet and hydric landscapes has the soil as the key subject. This shows how risk can become a resource while the environmental damage can 
be remedied. Fundamental elements in the design strategies were the integration of different disciplines and principles in the remediation process built by design: context based projects, fostering Public Nature, sustaining Environmental Ethics and supporting Hypernature. The intervention techniques are different from places to place, to cleanse and to prevent pollution caused by floods to preserve environmental qualities: from soil washing, to the creation of new resilient urban landscapes.

The research in this field arises as a vision of reconciliation, between the cities and the exploited soils through the activation of natural processes, between the sciences and the arts, in an action of care and responsibility for the present and the future of our cities and our living environment. As evidenced by both the continuous evolution of logic and techniques, this discussion is a fertile and complex field in which we face the necessary conjunction between the aesthetic experience, the scientific research and ethical responsibility.

Author Contributions: The authors of the essay wrote the entire content of the article together. F.M. wrote paragraph 3, I.C. paragraph 4 and L.V.F. paragraph 5. All authors have read and agreed to the published version of the manuscript.

Funding: This research received no external funding.

Conflicts of Interest: The authors declare no conflict of interest.

\section{References}

1. Bot, A.; Benites, J. The Importance of Soil Organic Matter; FAO Land and Plant Nutrition Management Service: Rome, Italy, 2005.

2. Albrecht, B. Conservare il Futuro. Il Pensiero della Sostenibilità in Architettura, 1st ed.; Il Poligrafo: Padova, Italy, 2012.

3. MacHarg, I. Design with Nature, 25th ed.; John Wiley \& Sons Inc.: Hoboken, NJ, USA; New York, NY, USA, 1995.

4. Meyer, E.K. Sustaining Beauty: The Performance of Appearance. J. Landsc. Archit. 2008, 3, 6-23. [CrossRef]

5. Meyer, E.K. Uncertain Parks: Disturbed Sites, Citizens, and Risk Society. In Large Parks; Julia, C., George, H., Eds.; Princeton architectural Press: New York, NY, USA, 2007.

6. Koolhaas, R. Mutations. Harvard Project on the City, 1st ed.; ACTAR: Barcelona, Spain, 2002.

7. Morgia, F. Catastrofe istruzioni per l'uso, 1st ed.; Meltemi: Roma, Italy, 2007; pp. 96-98.

8. Zeunert, J. Landscape Architecture and Environmental Sustainability: Creating Positive Change through Design, 1st ed.; Bloomsbury: London, UK, 2016.

9. Ceschin, S.; Sgambato, V.; Ellwood, N.T.W.; Zuccarello, V. Phytoremediation performance of Lemna communities in a constructed wetland system for wastewater treatment. Environ. Exp. Bot. 2019, 162, 67-71. [CrossRef]

10. Fare l'ambiente; Lotus Navigator 2002, n. 5; Editoriale Lotus: Milano, Italy, 2002; pp. 64-69.

11. Oakes, B. Sculpting with the Environment; John Wiley \& Son: Hoboken, NJ, USA; New York, NY, USA, 1995.

12. AMD\&ART. The Project: 1994-2005; AMD\&ART Inc.: Vintondale, PA, USA, 2003.

13. Beardsley, J. Earthworks and Beyond: Contemporary Art in the Landscape, 4th ed.; Abbeville Print: New York, NY, USA, 2006.

14. Corner, J. Recovering Landscape: Essays in Contemporary Landscape Architecture, 1st ed.; Princeton Architectural Press: New York, NY, USA, 1999.

15. Miller, F.P.; Vandome, A.F.; McBrewster, J. James Corner, 1st ed.; Alphascript Publishing-AbeBook: New York, NY, USA, 2010.

16. Kongjian, Y. Tianjin Qiaoyuan Let Nature do its Work: Adaptive Palette. In Urban Environment Design; Turenscape: Beijing, China, 2013; pp. 120-123.

17. Padoa Schioppa, C. Kongjian Yu. Turenscape 1998-2018; Librìa: Melfi, Italy, 2019.

18. Peter, L. The Idea of Making Time Visible. In Topos Magazine; Georg GmbH \& Co. KG: München, Germany, 2000; pp. 94-99.

19. Douglas Wright Develops the Gas Work Park Case Study in. Available online: https://www.webpages. uidaho.edu/larc301/lectures/remediation2.htm (accessed on 6 October 2020). 
20. EEA, Heavy Precipitation in Europe. Available online: www.eea.europa.eu/data-and-maps/indicators/ precipitation-extremes-in-europe-3/assessment-1 (accessed on 8 August 2020).

21. Ferretti, L.V. Paesaggio Urbano, Spazio Urbano; FrancoAngeli: Milano, Italy, 2019.

22. Palazzo, D.; Steiner, F. Urban Ecological Design; Island Press: Washington, DC, USA, 2011.

23. Corajoud, M. Esplorare i limiti, oltrepassarli. In Questo è Paesaggio. 48 definizioni; Zagari, F., Ed.; Mancosu: Roma, Italy, 2006; pp. 176-179.

24. Donadieu, P. Les Paysagistes. Ou les Métamorphoses du Jardinier; Arles/Versailles, Actes sud/École Nationale Supérieure de Paysage: Versailles, France, 2009; p. 43.

25. Terrin, J.J. A cura di, Villes Inondables. Prévention, Adaptation, Resilience; Editions Parenthèses: Marseille, France, 2014.

26. Benoit, R. Le Paysagisme: Source et Ressource pour L'urbanisme?" In Projets de Paysage 11/07/2018. Available online: http://www.projetsdepaysage.fr/fr/le_paysagisme_source_et_ressource_pour_l_urbanisme (accessed on 8 September 2020).

27. Mariano, C.; Marino, M. Public Space and climate change. Innovative planning approaches for the urban regeneration of coastal cities. In Proceedings of the International Conference on Changing Cities IV, Chania, Greece, 24-29 June 2019.

28. Caramaschi, S. Beyond Landscape (and) Urbanism. Una riflessione sull'atteggiamento paesaggistico nella trasformazione della città contemporanea. In Resilienza, Rigenerazione, Coevoluzione dei Sistemi Urbani, Atti della Conferenza Nazionale della SIU; Planum Publisher: Milano, Italy, 2019.

29. POPSU_Plate-forme d'Observation des Projets de Strategies Urbaines. Les Zones Inondables dans la ville: Renouvellement des Approaches urbaInes et des Projets Architecturaux, Actes du colloque; 10 e 11 marzo 2014, Amsterdam et Rotterdam. Available online: http://www.popsu.archi.fr/sites/default/files/nodes/ document/922/files/actes-popsu-2-du-seminaire-de-rotterdam_1.pdf (accessed on 8 September 2020).

30. Fratini, F. HafenCity, Hamburg: An integrated project. In Urbanistica Informazioni; INU Edizioni: Roma, Italy, 2014.

31. Howe, C.; Mitchell, C. (a cura di), Water Sensitive Cities; IWA Publishing: London, UK; New York, NY, USA, 2012.

32. Ashok, K.; Sharma Gardner, T.; Begbie, D. Approach to Water Sensitive Urban Design; Elsevier Science \& Technology: Amserdam, The Netherlands, 2018.

33. Urban Adaptation to Climate Change in Europe. Available online: www.eea.europa.eu/publications/urbanadaptation-to-climate-change (accessed on 8 September 2020).

34. Centro di Ricerca sui Consumi di Suolo. TERRA! Conservare le superfici, tutelare la risorsa: Il suolo, un bene comune; Maggioli Editore: Santarcangelo di Romagna, Italy, 2012.

35. Commission Européenne. Lignes Directrices Concernant les Meilleures Pratiques Pour Limiter, Atténuer ou Compenser l'imperméabilisation des Sols; Office des publications de l'Union Européenne: Luxembourg, 2012.

36. Commoner, B. The Closing Circle: Nature, Man and Technology; Knopf: New York, NY, USA, 1971.

37. Sorlini, S.; Riganti, V. (a cura di) Inquinanti Emergenti nelle Acque a uso Umano; Maggioli Editore: Santarcangelo di Romagna, Italy, 2019.

38. Skousen, J.; Simmons, J.; McDonald, L.M.; Ziemkiewicz, P. Acid-base accounting to predict post-mining drainage quality on surface mines. J. Environ. Qual. 2002, 31, 2034-2044. [CrossRef] [PubMed]

39. Bodner, G.; Nakhforoosh, A.; Kaul, H.-P. Management of Crop Water under Drought: A Review. Agron. Sustain. Dev. 2015, 35, 401-442. [CrossRef]

40. Trenberth, E.K. The Impact of Climate Change and Variability on Heavy Precipitation, Floods, and Droughts. In Encyclopedia of Hydrological Sciences; Anderson, M.G., Ed.; John Wiley \& Sons, Ltd.: Hoboken, NJ, USA, 2005.

Publisher's Note: MDPI stays neutral with regard to jurisdictional claims in published maps and institutional affiliations. 